\title{
THE EFFECT OF GUN SHOWS ON GUN-RELATED DEATHS: EVIDENCE FROM CALIFORNIA AND TEXAS
}

\author{
Mark Duggan \\ Randi Hjalmarsson \\ Brian A. Jacob \\ Working Paper 14371 \\ http://www.nber.org/papers/w14371
}

\author{
NATIONAL BUREAU OF ECONOMIC RESEARCH \\ 1050 Massachusetts Avenue \\ Cambridge, MA 02138 \\ October 2008
}

We would like to thank Andrew Cantor, Brittani Head, Josh Hyman, Rebecca Kahane, JD LaRock, Emily Owens, Petko Peev, and Paul Vernier for their excellent research assistance. We also thank David Hemenway, Ilyana Kuziemko, Jens Ludwig, and participants of the MPRC

NBER working papers are circulated for discussion and comment purposes. They have not been peerreviewed or been subject to the review by the NBER Board of Directors that accompanies official NBER publications.

(C) 2008 by Mark Duggan, Randi Hjalmarsson, and Brian A. Jacob. All rights reserved. Short sections of text, not to exceed two paragraphs, may be quoted without explicit permission provided that full credit, including $\odot$ notice, is given to the source. 
The Effect of Gun Shows on Gun-Related Deaths: Evidence from California and Texas Mark Duggan, Randi Hjalmarsson, and Brian A. Jacob

NBER Working Paper No. 14371

October 2008

JEL No. H0,I1,K4

\begin{abstract}
$\underline{\text { ABSTRACT }}$
Thousands of gun shows take place in the U.S. each year. Gun control advocates argue that because sales at gun shows are much less regulated than other sales, such shows make it easier for potential criminals to obtain a gun. Similarly, one might be concerned that gun shows would exacerbate suicide rates by providing individuals considering suicide with a more lethal means of ending their lives. On the other hand, proponents argue that gun shows are innocuous since potential criminals can acquire guns quite easily through other black market sales or theft. In this paper, we use data from Gun and Knife Show Calendar combined with vital statistics data to examine the effect of gun shows. We find no evidence that gun shows lead to substantial increases in either gun homicides or suicides. In addition, tighter regulation of gun shows does not appear to reduce the number of firearms-related deaths.
\end{abstract}

Mark Duggan

University of Maryland

Department of Economics

3115L Tydings Hall

College Park, MD 20742

and NBER

duggan@econ.bsos.umd.edu

Randi Hjalmarsson

School of Public Policy

2101 Van Munching Hall

University of Maryland

College Park, MD 20742

rhjalmar@umd.edu

\author{
Brian A. Jacob \\ Gerald R. Ford School of Public Policy \\ University of Michigan \\ 735 South State Street \\ Ann Arbor, MI 48109 \\ and NBER \\ bajacob@umich.edu
}




\section{Introduction}

Thousands of gun shows take place in the United States each year. Gun control advocates argue that the "gun show loophole" makes it easier for potential criminals to obtain a gun; the loophole basically allows unlicensed vendors at gun shows to sell firearms without conducting background checks on purchasers. In support of this claim, gun control advocates commonly cite selected extreme events, such as the April 20, 1999 Columbine High School shooting during which Eric Harris and Dylan Klebold shot 26 students, killing 13. Subsequent investigations by the Bureau of Alcohol, Tobacco, Firearms, and Explosives (ATF) revealed that some of the weapons used in the shooting were purchased for Harris and Klebold by a friend at a gun show (Brady Campaign, 2005). Though not an issue generally raised by gun control advocates, one might also be concerned that gun shows would exacerbate suicide rates by providing individuals considering suicide with a more lethal means of ending their lives.

On the other hand, proponents argue that gun shows are innocuous since potential criminals can acquire guns quite easily through other black market sales or theft. Gun lobbyists often cite a Bureau of Justice Statistics survey that finds that only $0.7 \%$ of state prison inmates who had ever owned a gun reported that they obtained it at a gun show (Harlow, 2001).

Yet, in response to the concerns about gun shows, 18 states have closed the "gun show loophole” by passing legislation that regulates the private transfer of firearms and 6 states have imposed additional regulations on gun shows. ${ }^{1}$ Despite this legislative activity, there is little empirical evidence regarding the effect of gun shows. This stems in large part from the difficulty of obtaining detailed information on gun shows and outcomes such as crime or

\footnotetext{
${ }^{1}$ States became particularly attentive to the gun show loophole after the 1999 Columbine incident and again after the 2007 Virginia Tech massacre. Even though the weapons used in the Virginia Tech shooting were purchased at federally licensed stores and not gun shows, the Virginia Tech review panel put together a report that recommended requiring background checks for firearms sales at gun shows. Governor Kaine made it a priority to enact such a law in 2008, but it was defeated in the Virginia Senate.
} 
mortality. Moreover, because the timing and location of gun shows is clearly not random, it is difficult to infer the causal impact of gun shows by simply comparing areas (i.e., states or counties) with frequent gun shows to those with fewer shows.

In this paper, we examine the impact of gun shows on gun and non-gun suicides and homicides as well as accidental gun deaths using a unique data set that combines information on the date and location of gun shows from Gun and Knife Show Calendar, vital statistics mortality data, and census data for the states of Texas and California. The data includes all gun shows and deaths occurring in the two states over an eleven year period (1994 to 2004) and are organized at the week by zip code level. We focus our attention on homicides and suicides given that these represent more than 96 percent of all 66,513 firearm-related deaths in the two states during our eleven-year study period. From 1994 to 2004, there are more than 2,200 gun shows in Texas and almost 1,200 gun shows in California. During this period, there are more than 45,000 homicides and 60,000 suicides in California and Texas.

These two states were selected for a number of reasons. Texas and California are the nation's two most populous states, comprising approximately $20 \%$ of the total U.S. population, and contain a significant number of the country's gun shows. In addition, they are at opposite ends of the spectrum in terms of the degree of gun show regulation. California is known for having the most aggressive gun show regulations, including background checks for all gun show purchasers and a ten-day waiting period to obtain the gun. Texas, on the other hand, has no such regulations. Thus, one might expect to find a very different effect of gun shows in these two regulatory environments. This is particularly relevant in light of the Supreme Court's 2008 ruling that the District of Columbia's 32-year old ban on handguns is incompatible with gun rights under the Second Amendment. 
To address the potentially endogenous timing and location of gun shows, we examine outcome trends within jurisdictions where gun shows occur, exploiting the high frequency variation in deaths that we observe in the vital statistics data. Our baseline empirical specification estimates the impact of a gun show on the number of deaths in a zip code in the week of a show and the three subsequent weeks, controlling for zip code by year fixed effects as well as month fixed effects. Because zip codes are quite small and because the zip codes in which gun shows occur may be primarily commercial (e.g., a convention center) and attract many attendees from outside the immediate zip code, we also estimate specifications that utilize the number of gun shows that take place within various distances to the "home" zip code.

The results of our study generally indicate that gun shows do not have substantial impacts on either gun homicides or suicides. While there is some evidence of statistically significant effects in both California and Texas, these effects are relatively modest in size. For example, our findings indicate that in the average year from 1994 to 2004, there are four additional gun suicides in the entire state of California resulting from the 102 gun shows occurring in the average year. Moreover, this increase is offset entirely by an almost identical decline in the number of non-gun suicides, suggesting that gun shows influence the method but not the number of suicides. We find no evidence to suggest that gun shows increased the number of homicides in California during our study period.

Of course, given that California has very stringent regulations of firearms generally and gun shows specifically, the results for this state may not generalize to other states. It could be that the background check requirements, ten-day waiting period, and so forth reduce the average effect of gun shows on mortality below what it otherwise would be. If true, one would then 
expect to detect an effect in states with the least stringent regulation of gun shows, such as Texas.

But our results provide little evidence of a gun show-induced increase in mortality in Texas. In fact, we find that in the two weeks following a gun show, the average number of gun homicides declines in the area surrounding the gun show. Aggregating across all gun shows in the state, we find that there are approximately 16 fewer gun homicides resulting from the 200 gun shows in the average year. In the sections below, we discuss several possible explanations for this counterintuitive finding. However, it is important to keep in mind that while these results are statistically significant, they are quite small - representing just one percent of all homicides in Texas in the average year. We find no evidence of an effect on suicides or non-gun homicides in Texas.

There are several limitations to the analysis. We only examine the geographic areas in and around where gun shows take place. To the extent that guns obtained at shows are transported elsewhere, we will not pick up these effects. In addition, our identification strategy relies on high frequency variation that, by definition, focuses on short-term effects. Specifically, we look for spikes in various measures of mortality in the four weeks immediately following a gun show. However, guns are durable and can be used many years in the future. Our identification strategy will not pick up these long-run effects.

Despite these limitations, we believe that this analysis makes an important contribution to understanding the influence of gun shows, the regulation of which is arguably the most active area of federal, state, and local firearms policy. To our knowledge, this is the first study that directly examines the impact of gun shows on gun-related deaths. ${ }^{2}$

\footnotetext{
${ }^{2}$ Lott (2003) uses aggregate, annual state-level data to investigate the effect of gun show regulations such as background check requirements on state-level crime rates.
} 
The remainder of the paper proceeds as follows. Section II provides important background information on gun ownership and the institutional and legal arrangements surrounding gun shows. Sections III and IV describe the relevant literature and data used in the analysis, respectively. Section V outlines our empirical strategy. Section VI presents our main results and Section VII concludes.

\section{Background}

\section{Gun Ownership in the U.S.}

The manufacture and sale of firearms in the United States is substantial. According to the U.S. Department of the Treasury's Bureau of Alcohol, Tobacco and Firearms (2002), there are more than 1,700 licensed firearms manufacturers and almost 750 licensed importers in the United States. In 2006, approximately 1.4 million handguns and 2.2 million shotguns and rifles were manufactured in the U.S., with just 0.3 million of these firearms exported outside of the U.S. (U.S. Department of the Treasury, 2008). According to Census Bureau statistics published by Shooting Industry magazine ${ }^{3}$, an additional 1.1 million handguns and 0.7 million rifles and shotguns were imported into the U.S. in the same year, implying that more than 5 million new firearms were available for sale in that year.

Statistics on private gun ownership in the United States vary slightly across different studies. The most widely cited estimate of private gun ownership in the United States comes from the National Survey of Private Ownership of Firearms (NSPOF), which was conducted in 1994 for the Police Foundation under the sponsorship of the National Institute of Justice. According to an analysis of the NSPOF data by Cook and Ludwig (1996), there are approximately 192 million privately-owned firearms in the United States, of which 65 million

\footnotetext{
${ }^{3}$ See http://www.shootingindustry.com/Pages/SpecRep6.html\#importhand accessed on August 29, 2008.
} 
are handguns. Cook and Ludwig (1996) estimate that 44 million people, representing about 35\% of American households, own a gun. Further, they find that many people who have guns own several: according to their analysis, three-quarters of all guns are owned by people who own four or more. This group, they estimate, amounts to just $10 \%$ of American adults.

By contrast, the Bureau of Alcohol, Tobacco and Firearms (U.S. Department of the Treasury, 2000) estimated that as of the end of 1996, approximately 242 million firearms were available for sale or owned by civilians in the U.S. That total included roughly 72 million handguns, 76 million rifles, and 64 million shotguns. A slightly higher estimate of U.S. household gun ownership comes from the 1997-98 National Gun Policy Survey (National Opinion Research Center, 1998), which found that 39\% of American households have some type of gun, and $24 \%$ of households have a handgun.

\section{Institutional Background on Gun Shows}

Thousands of gun shows are held in the U.S. each year at convention centers, fairgrounds, civic centers, hotels, armories, VFW halls and other locations. The majority of gun shows are promoted by a core group of about 175 organizations and individuals. Gun shows are generally open to the public, and attendees often pay a modest admission fee to attend. Most shows are held over the weekend and last for two days, drawing an average of 2,500 to 5,000 people per show. To rent a table from a promoter, vendors pay fees typically ranging from $\$ 5$ to $\$ 50$. The number of tables at gun shows ranges widely, from as few as 50 to as many as 2,000 (U.S. Departments of Justice and Treasury, 1999). ${ }^{4}$

\footnotetext{
${ }^{4}$ Various types of firearms are sold at gun shows. These include new and used handguns, shotguns, rifles, and curio or relic firearms (e.g., firearms of historical interest). Semiautomatic assault weapons may be sold at gun shows if they were manufactured before 1994, and large capacity magazines and machine gun parts also may be sold if they were manufactured before certain dates. In addition, gun show vendors also usually sell ammunition, gun literature,
} 
Lott (2003) states that roughly 1,900 gun shows were held in the U.S. in 1991 and that this number increased to a high of 2,907 in 1996, but then declined to roughly 2,400 in 2001. He finds that western and rural states tend to have the greatest number of gun shows per capita, and that states with higher gun ownership rates have significantly more gun shows. In 1998, for example, Wyoming, Montana, South Dakota, Oregon and West Virginia topped his list of shows per 100,000 residents, while Connecticut, Alaska, Massachusetts, New Jersey and Hawaii had the lowest per capita rates. A group of federal agencies using the same data source (a periodical titled Gun Show Calendar) came up with a much higher figure for the overall number of gun shows in $1998-4,442$ shows compared with the 2,600 reported by Lott (2003). States with the most gun shows included Texas, Pennsylvania, Florida, Illinois, and California (U.S. Departments of Justice and Treasury, 1999).

Private citizens can acquire firearms through a number of channels, including gun stores, department stores, pawnshops, the mail, family members, and friends. The share of guns that private individuals acquire through gun shows appears to be relatively small. The NSPOF estimated that in 1993 and 1994, approximately 239,000 firearms were bought annually at gun shows and flea markets in the U.S. This represents $4 \%$ of both long guns and handguns acquired by private individuals from all sources in those years (Cook \& Ludwig, 1996). Similarly, a 1997 survey of 18,000 state prison inmates by the Bureau of Justice Statistics found that only $0.7 \%$ and $1.7 \%$ of inmates who had ever owned a gun said they had obtained it at a gun show or flea market, respectively (Harlow, 2001). Despite this, an ATF study (2000) found that $14 \%$ of their criminal trafficking investigations between 1996 and 1998 involved guns purchased from gun shows; about $46 \%$ involved straw purchases (i.e. when an individual purchases a gun for offer firearms for both those seeking to purchase handguns, as well as the sportsman and hunter. (U.S. Departments of Justice and Treasury, 1999). 
someone else) and $20 \%$ involved unlicensed sellers. ${ }^{5}$ This suggests that while relatively few criminals may themselves make a purchase at a gun show, a much larger number may obtain a gun from someone who previously did purchase at a show.

\section{The Gun Show Loophole}

Certain individuals - primarily felons and those convicted of domestic abuse - are prohibited from purchasing or possessing a firearm under federal law. ${ }^{6}$ The "gun show loophole” refers to the fact that federal law requires "federal firearms licensees" (FFLs) (i.e., those licensed by the government to manufacture, import, or deal in firearms) to conduct background checks on non-licensed persons seeking to obtain firearms, but does not require such checks by those who transfer firearms and do not meet the statutory test of being "engaged in the business" to do so (Krouse, 2005). Therefore, while a gun dealer who operates a gun shop is obliged to conduct background checks on potential buyers under federal law, private sellers at gun shows who "transfer" firearms are not obliged to conduct background checks of potential buyers. FFLs comprise $50 \%$ to $75 \%$ of the vendors at most gun shows, so some private venders could use this "loophole" to entice potential customers to their tables (U.S. Departments of Justice and Treasury, 1999). As a result, some assert that it is easy for criminals to obtain guns simply by purchasing them at gun shows (Krouse, 2005).

While federal law does not regulate sales at gun shows, a number of states have passed legislation regulating at least some of these sales. The most common type of regulation is the

\footnotetext{
${ }^{5}$ http://www.atf.treas.gov/pub/fire-explo_pub/pdf/followingthegun_internet.pdf

${ }^{6}$ There are eight categories under the Brady Act that render individuals ineligible to purchase or possess firearms. These include: felony convictions, misdemeanor convictions, fugitive status, an adjudication of mental illness, issuance of a restraining order against the individual, people convicted of drug-related offenses, underage status, or alien status. Many state laws contain these same prohibitions. In addition, some state laws also prohibit people convicted of alcohol offenses and juvenile offenses from buying or possessing firearms (U.S. Department of Justice, Bureau of Justice Statistics, 2003b).
} 
requirement of a background check, which is determined through an investigation of criminal records kept by the FBI or state “point of contact” agencies (POC's) such as local and state police agencies. ${ }^{7}$ For example, the states of California and Rhode Island along with the District of Columbia require background checks on all gun purchases, including those that occur at gun shows. Five additional states (Colorado, Connecticut, Illinois, New York, and Oregon) have less comprehensive regulations but do require background checks for all firearms purchases occurring at gun shows (LCAV, 2008). The vast majority of states, however, do not require a background check for transactions occurring at gun shows.

One recent study (Wintemute, 2007) compared gun shows in California, which is considered to have "a uniquely restrictive regulatory environment for gun shows”, with shows in Arizona, Nevada, Texas, and Florida. These four states do not regulate transactions at gun shows or any private party firearms sales. In addition to the background checks described above, California requires that any individual who purchases a gun, whether at a gun show or anywhere else, wait ten days before receiving the gun. ${ }^{8}$ The results from this study suggest that there were fewer illegal "straw purchases” and undocumented gun sales at California's shows. Given this finding, one might expect to find a very different effect of gun shows in a state such as California with aggressive regulations than in a state such as Texas with no such regulations. We investigate this issue in the sections that follow.

\footnotetext{
${ }^{7}$ National figures on background checks are kept by the Bureau of Justice Statistics. In 2005, there were 8.3 million background checks, with 131,900 of these leading to a purchase denial.

${ }^{8}$ Additional gun show specific regulations that exist in California are described in California Penal Code 12071.4, which is also known as the Gun Show Enforcement and Security Act of 2000. For instance, this includes the requirement that each vendor at a gun show submits his personal information (name, birth date, driver's license number) as well as that of his employees to the producer of the show. It is also important to note that regulations that apply to the purchase of a firearm at a location other than a gun show generally apply to gun show purchases as well.
} 


\section{Prior Literature}

Prior Evidence on the Relationship between Guns, Crime, and Suicide

A large body of previous research has investigated the effect of gun ownership on crime. Much of this work exploited variation over time at the national level in rates of gun sales or ownership (Kleck, 1984) or across areas at a point in time (Cook, 1983). One concern with much of this earlier work is that the factors that influence variation across time or areas in gun ownership may themselves exert an independent effect on crime and not all of these factors may be observable in the available data.

To address this concern, Lott and Mustard (1997) use the passage of state concealed weapons laws to estimate the effect of guns on homicide, robbery, and other types of crime. Their findings indicate that crime declined in those states that passed concealed weapons laws, suggesting that gun ownership reduces crime through deterrence. This study was then the focus of much subsequent work, some of which was supportive (Moody, 2001) and some which found that the results were not robust to a variety of assumptions and modeling choices (Ayres and Donohue, 1999; Black and Nagin, 1998).

Two more recent studies estimate the effect of increases in gun ownership on crime using panel data on crime and estimated gun ownership for the 1980s and 1990s (Duggan, 2001; Cook and Ludwig, 2004). Both studies found that increases in gun ownership led to increases in the homicide rate with little corresponding effect for other types of crime. Interestingly, the entire effect for homicide was attributable to gun homicides in both studies.

A similarly large body of work has explored the effect of gun ownership on the suicide

rate. This is perhaps not surprising given that, according to the National Center for Health Statistics, more than 50\% of all suicides committed in the U.S. in 2005 involved a firearm. 
Many of these studies have found that gun owners are significantly more likely to take their own lives than their observably similar counterparts without a gun (Kellermann et al. 1992, Sloan et al. 1990, Loftin et al. 1991) and that states with greater gun ownership have higher suicide rates (Azrael, Hemenway, and Miller, 2002).

One challenge for this area of research is that firearm owners are likely to systematically differ in unobserved ways from their counterparts who do not own a firearm. For instance, Duggan (2003) documents that both the gun and the non-gun suicide rates are higher in states with high rates of gun ownership. To address this concern, Ludwig and Cook (2000) examine whether the implementation of the Brady Act, which required that licensed firearms dealers observe a 5-day waiting period and initiate a background check for handgun sales, was associated with a reduction in the suicide rate in the 32 states that were affected by the requirements versus the 18 states that were not; the latter group of states already met the requirements of the Brady Act. By interrupting the sale of a handgun and making the purchaser wait, the Brady Act gives the purchaser time to change his mind. However, the authors' evidence suggests that the policy only lowered the suicide rate for individuals age 55 and older.

Taken together, the results from this research suggest that there is a relationship between gun ownership rates and both gun suicide and gun homicide rates. Though not completely in agreement, much of the literature indicates that this relationship is positive; i.e. increases in gun ownership rates are associated with increases in gun homicide and suicide rates.

\section{Prior Evidence on the Effects of Gun Shows}

Yet, despite the evident relationship between gun ownership and homicide and suicide rates, there has been little empirical study of the effects of gun shows on crime and, to our 
knowledge, no studies of the effect of gun shows on gun suicides or accidental deaths. In a widely cited study, the BATF reviewed a random sample of 314 ATF investigations between 1991 and 1998 involving gun shows, and found that felons buying or selling firearms were involved in more than $46 \%$ of the investigations. In addition, the study found that in more than a third of the gun show investigations reviewed, the firearms involved were known to have been used in subsequent crimes, including homicide, robbery, burglary, assault and drug offenses (U.S. Departments of Justice and Treasury, 1999). It is not clear how to interpret these results, however, since the sample is constructed to only include shows that were under investigation.

Using aggregate annual state level data and controlling for state and year fixed effects as well as a number of demographic variables, Lott (2003) finds that laws requiring background checks at gun shows are negatively associated with the prevalence of gun shows in a state. ${ }^{9}$ In the same analysis, Lott examines violent crime rates before and after the introduction of state laws to require background checks for private transfers of handguns. Using a similar empirical specification, he compares nine states that closed this loophole by 1994 to 33 states that never implemented such laws and finds no evidence that these gun show laws reduced violent crime. In fact, he finds that such laws are positively associated with murder, robbery, and auto theft.

\section{Data}

\section{Data Description}

To investigate whether the number of deaths changes in the weeks leading up to or following a gun show, we compiled a unique data set of gun show and mortality information for the states of Texas and California. These data are organized at the zip code by week level. In

\footnotetext{
${ }^{9}$ He also provides evidence that state laws banning assault weapons and/or imposing waiting periods reduce the number of gun shows.
} 
particular, we determined the number of gun shows in each week from 1994 to 2004 in each zip code. This gun show data was then combined with zip code by week mortality data, including various types of gun deaths, as well as demographic and socioeconomic characteristics from the 2000 census. Finally, using the latitude and longitude of the centroid of each zip code listed in the 2000 census, we calculated the number of gun shows in a given week within 5, 10, and 25 miles of each zip code. This allows us to account for the fact that that there are likely to be many individuals who attend the gun show but who do not live in the same zip code as the show.

We aggregate the data to the zip code by week level (rather than zip code by date) to: (i) increase statistical precision and (ii) account for the fact that gun shows typically occur on weekends, when mortality likely would be different than on other days for reasons unrelated to gun shows. Using a symmetric time period as our unit of observation also reduces the possibility that pre-post comparisons will be driven by factors other than the existence of a gun show. Because gun shows typically begin on either Friday or Saturday, we begin each week on a Friday and end it on a Thursday. Therefore, the first week of data begins on Friday, January 7, 1994 and the last week ends on Thursday, December 30, 2004; this results in 573 weeks of data.

Information on gun shows was obtained from Gun and Knife Show Calendar, a national magazine that lists the dates and locations of gun shows throughout the country. For each Texas and California gun show from 1994 to 2004, we especially noted the zip code of the gun show location as well as the date(s) of the show. Figure 1 presents the annual number of gun shows over this eleven-year period: there are 2,221 shows in Texas and 1,196 in California. In both states, a decline in the prevalence of gun shows is observed. The number of shows decreased from 125 in 1994 to 77 in 2004 in California, with a peak of 173 in 1996, and from 245 in 1994 to 191 in 2004 in Texas, with a minimum of 157 in 2001 . It is important to note, however, that 
the location of gun shows is not evenly distributed across zip codes. For instance, only 120 Texas zip codes and 98 California zip codes have at least one gun show; 63 and 46 zip codes, respectively, have five or more shows over the sample period. We will return later in this section to a more in depth analysis of where gun shows occur.

To examine the impact of gun shows on various types of mortality, we utilize individuallevel vital statistics data for the states of Texas and California. ${ }^{10}$ We focus on detailed information about the deaths of all residents of these states from 1994 to 2004, i.e. corresponding to the available gun show data. ${ }^{11}$ Over this time period, there were 1,609,203 deaths of any type in Texas and 2,496,589 deaths in California. Following previous research, we use the International Classification of Disease cause-of-death codes in our mortality data to focus on those deaths that would be potentially influenced by firearms availability, including homicides, suicides, and deaths resulting from the accidental discharge of a firearm. A fourth category that can be defined includes deaths that are firearm related, but for which the cause is undetermined; that is, it is not clear whether the death is accidental or committed with intent.

For each year and state, Figure 2 plots the total number of gun deaths in each of these four categories. In both California and Texas, the greatest number of gun deaths occurs in 1994. During this first year of data, there are 3,368 gun deaths in Texas and 4,994 in California. Similar trends in the number of gun deaths over the sample period are seen in both states. The number of gun deaths decreases until 1999 in California and 2000 in Texas; after these years, the trend reverses slightly and the number of gun deaths remains fairly constant until the end of the sample. For instance, the number of gun deaths decreases by more than $41 \%$ (2,079 deaths) in

\footnotetext{
${ }^{10}$ The California data was obtained from the Office of Health Information and Research in the California Center for Health Statistics (CAHS). The Texas data was obtained from the Center for Health Statistics in the Texas Department of State Health Services.

${ }^{11}$ We focus on deaths of 'state' residents to be consistent across states. For instance, while the California data set also includes deaths of non-Californians occurring in the state of California, the Texas data set does not.
} 
California between 1994 and 1999; from 1999 to 2004 there is an increase of just over 6\% (267 deaths). Similar patterns are also observed for both gun suicides and gun homicides, and thus the trend in gun deaths is not being driven by any one category of death.

While Figure 2 indicates that similar trends in the level of gun deaths are observed across these two states, it is important to note that the percent of homicides and suicides committed with a gun varies both across states and over time. In a typical year over this sample period, $62.2 \%$ of Texas suicides are committed with a gun compared to $48.4 \%$ of California suicides. Though California has the lower gun suicide rate, it actually has a higher proportion of homicides committed with a gun: $71.9 \%$ compared with $64.2 \%$ in Texas. To put these statistics in a national context, note that in $2003,53.7 \%$ and $67.2 \%$ of the suicides and homicides, respectively, in the United States were committed with a firearm. The remainder of the paper focuses on homicides and suicides, given that these two categories make up more than $96 \%$ of all gun deaths in Texas and California from 1994 to 2004.

To merge the mortality and gun show data, we also identify the date and zip code of residence for each death. We drop from the analysis: (i) deaths with incomplete zip code information ( $0.9 \%$ in Texas and none in California), (ii) zip codes not listed in the 2000 Census (since 5, 10, or 25 mile distances cannot be calculated), (iii) weeks for which a four-week lead or lag cannot be created, since many specifications will look at the four weeks leading up to and following a gun show, and (iv) zip codes that have either zero population or zero land area. Taken together, this implies a reduction in the number of Texas and California gun shows by $10.2 \%$ and $5.9 \%$, respectively, and a reduction in the total number of deaths by $3.3 \%$ and $3.1 \%$, respectively. The final sample includes 1,053,326 observations in Texas (566 weeks * 1,861 zip codes) and 941,824 observations in California (566 weeks * 1,664 zip codes). Within this 
sample, there were 1,556,113 deaths and 1,995 gun shows in Texas and 2,421,339 deaths and 1,126 gun shows in California.

\section{$\underline{\text { Summary Statistics }}$}

Table 1 provides summary statistics for the mortality data. For each state, we present the average weekly number of gun-related deaths per capita separately for: (i) all zip codes, (ii) zip codes with at least one gun show from 1994 to 2004, (iii) zip codes with at least one gun show in a 10-mile radius, and (iv) zip codes with zero gun shows. The table indicates that zip codes with a gun show or a nearby gun show look different than zip codes with no gun shows. For instance, in California, the average per capita number of weekly gun deaths is about 74 percent greater in the 1,566 zip codes that have no gun shows than in the 98 zip codes with at least one gun show and 38 percent greater when compared to the 901 zip codes with a show within 10 miles. These differences are driven by the per capita number of gun suicides. In contrast, the per capita number of weekly gun deaths in the 1,741 Texas zip codes without a gun show is just 22 percent greater than that in the 120 Texas zip codes with at least one show; this difference is again driven by gun suicides. Note that it is important to take the zip code population into account when comparing deaths across zip codes, as zip codes with larger populations are more likely to have gun shows (as we will shortly see) and will clearly have more deaths.

Table 1 also contrasts the average number of weekly gun deaths per capita for weeks with and without a gun show for the samples of zip codes with at least one gun show (see columns (3) and (4)) and those with a show within 10 miles (see columns (6) and (7)). No clear pattern across states emerges. For the most part in Texas, there is very little difference between the average number of weekly gun deaths, homicides, and suicides when comparing gun show and non-gun 
show weeks. In California, the average number of weekly gun deaths per capita differs slightly across gun show and non-gun show weeks when looking at zip codes that have at least one show. However, in these zip codes, the average number of weekly gun suicides per capita is smaller in gun show weeks than non gun show weeks while the opposite relationship is seen for gun homicides. The most striking differences across gun show and non-gun show weeks are seen in California zip codes that have at least one show within 10 miles. In these zip codes, there are almost twice as many gun deaths per capita in non-gun show weeks compared to gun show weeks; this difference is primarily driven by gun suicides, though the same pattern is seen for gun homicides.

It is important to note that while the statistics presented in Table 1 eliminate some of the heterogeneity across zip codes by comparing gun show and non gun show weeks in only the samples of gun show zip codes or zip codes with a close show, substantial heterogeneity still remains. Specifically, within the sample of zip codes with at least one gun show, for instance, there is also substantial variation in the number of weeks with a gun show; thus, some zip codes may be weighted more when considering gun show weeks. ${ }^{12}$

Additional summary statistics describing the number of weekly gun shows and deaths, as well as demographic measures, are presented in Appendix Table 1 for the samples of Texas and California zip codes with at least one gun show in a 10-mile radius. There are substantial differences between Texas and California zip codes, which support the decision to conduct the empirical analysis separately for these two states. For instance, the average number of weekly gun shows in a zip code (or a zip code within 10 miles) is more than twice as large in Texas than California. Yet, the average number of weekly deaths (including gun deaths) is higher in

\footnotetext{
${ }^{12}$ For example, a zipcode with 10 shows will contribute 10 times as much to the "gun show week" averages as will a zipcode with just one show.
} 
California. Population density is more than twice as large, on average, in California zip codes than Texas zip codes while Texas zip codes tend to be more rural. Racial composition is quite different across the two states: as compared with Texas, California's population has smaller fractions of White and Black, but larger fractions of Asian and multi-race. In addition, gun ownership - proxied for with the fraction of suicides committed with a gun, which is considered to be the most reliable proxy of gun ownership (Azrael, Cook, and Miller, 2004) - is substantially higher in Texas than California zip codes.

\section{Where and When Do Gun Shows Occur?}

To explore the characteristics of areas that have one or more gun shows, Table 2 presents summary statistics of demographic variables for zip codes with at least one gun show over the sample period in column (1) and zip codes with no gun shows in column (2). The difference in means for these two groups of zip codes and whether the difference is significant are presented in column (3). Parallel measures are presented in columns (4) through (6) for zip codes with and without at least one show in a 10-mile radius.

The results presented in Table 2 indicate that gun shows are significantly more likely to occur in: (i) more populated areas, (ii) more urban areas, (iii) more Hispanic areas, (iv) more Black areas, and (v) zip codes with fewer guns, again proxied for with the fraction of suicides committed with a gun. These significant differences are seen in both California and Texas. Gun shows are also more likely to be located in zip codes that are in a metropolitan statistical area (MSA); this difference is significant in the California 10-mile sample and both samples in Texas.

In addition, gun shows are not evenly dispersed over the course of a year. Regressions of the number of gun shows per week on month dummies indicate that there are significantly more 
gun shows in October and November relative to January while there are significantly fewer gun shows in May, June, and July.

\section{Empirical Strategy}

We are interested in examining the impact of gun shows on mortality, including suicides, homicides, and accidental gun deaths. The primary challenge stems from the fact that gun shows may occur in places, or at times, that have more deaths for other, unobserved reasons. For example, as we saw in Table 2, there is some evidence that gun shows occur in places where relatively fewer people own guns. Failing to account for this could lead to spurious estimates of the impact of gun shows on mortality. Similarly, the number of gun shows occurring in Texas and California during weeks in the second quarter of the year is significantly less than the number of gun shows in other quarters; once again, this could yield spurious results given the seasonal nature of homicide and suicide. To address this potential endogeneity, we examine outcome trends within jurisdictions where gun shows occur, exploiting the high frequency variation in deaths that we observe in the vital statistics data.

In our baseline model, we estimate specifications that take the following form:

$$
y_{z t}=n \text { showst } 0_{z, t}+\text { nshowstm } 1_{z, t-1}+\text { nshowstm } 23_{z, t-2, t-3}+\lambda_{t}+\gamma_{z t}+\varepsilon_{z t}
$$

where $y_{z t}$ is the number of deaths in zip code $z$ in week $t$, and the "nshows" variables indicate the number of shows that occurred in zip code $z$ in the contemporaneous week and in several prior weeks. The nshowst0 variable indicates the number of gun shows that took place in the contemporaneous week. Note that since most gun shows take place over the weekend, and we define weeks to run from Friday to Thursday, the coefficient on this variable will capture the effect of a gun show on gun deaths during the show and in the four or five days immediately 
following the show. The variable nshowstm 1 indicates the number of gun shows that took place in zip code $z$ in week $t-1$. Hence, the coefficient on this variable will capture the effect of a gun show on the number of gun deaths between 8 and 14 days following the start of the show. The variable nshowstm23 indicates the number of gun shows that took place in zip code $\mathrm{z}$ in weeks $t$ 2 or $t-3$, and thus captures the effect of a gun show on the number of deaths several weeks later. ${ }^{13}$

To account for unobservable location and period specific factors that might be correlated with the occurrence of gun shows as well as the number of gun-related deaths, we include a set of location*time period fixed effects, denoted above by $\gamma_{z t}$. In our baseline model, we include zip code*year fixed effects to capture location-specific factors that are either time-invariant or change slowly over time (e.g., demographic shifts, changes in police practice, etc.) as well as month fixed effects (e.g., separate indicators for January, February, etc.) to capture common seasonality-related trends across zip codes. We later show that our results are robust to a variety of alternative controls for unobserved location and/or time effects.

As an important sensitivity analysis, we estimate the following model that extends the specification in equation (1) to include a series of variables (i.e., the nshowst\# variables) that capture changes in mortality leading up to a gun show:

$$
\begin{aligned}
& y_{z t}=\text { nshowst } 0_{z, t}+\text { nshowstm } 1_{z, t-1}+\text { nshowstm } 23_{z, t-2, t-3}+ \\
& \text { nshowst } 1_{z, t+1}+\text { nshowst } 2_{z, t+2}+\text { nshowst } 34_{z, t+3, t+4}+ \\
& \lambda_{t}+\gamma_{z t}+\varepsilon_{z t}
\end{aligned}
$$

The nshowst\# variables reflect the number of gun shows that took place in zip code $z$ in weeks $t+1, t+2$, etc. These leading indicators serve two purposes. First, they serve as a test for the presence of unobserved factors that occurred close to the time of a gun show, and may be leading

\footnotetext{
${ }^{13}$ In preliminary analyses, we allowed the coefficient on the number of shows in these weeks to vary, but found no difference in the coefficient estimates. Hence, for the sake of parsimony, we present results from a model that restricts the effects to be the same across these weeks.
} 
to spurious correlations in equation (1). For example, if we see a large positive coefficient on the nshowst1 variable, indicating a spike in the number of gun-related deaths in the week preceding a gun show, we might be less willing to interpret a large positive coefficient on the nshowstm1 variable as evidence that gun shows lead to an increase in gun-related deaths. Second, they allow us to explore temporal substitution in the number of deaths that might be related to the presence of a gun show. For example, if potential criminals "wait" to commit their crimes until a gun show provides them an opportunity to purchase a firearm, then one might see a decline in deaths leading up to a gun show followed by a spike in deaths immediately after the show. In practice, we find that the inclusion of leading indicators does not change our results, and does not provide any indication of temporal substitution.

In the discussion above, we have focused on the relationship between gun shows and gun-related deaths in a particular zip code. However, zip codes are quite small. The median zip code in California (Texas) is only 17 (52) square miles, and the urban zip codes in which many gun shows occur are considerably smaller in terms of land area. Indeed, in some cases, the zip code in which a gun show occurs is primarily a commercial area with a negligible residential population. While there is no data on the residential location of gun show patrons, it seems likely that gun shows attract many people outside the immediate zip code. Thus, one might expect the presence of a gun show in a particular zip code to influence the number of gun-related deaths in neighboring zip codes.

If one had a strong reason to believe, ex ante, that gun shows attracted patrons within a certain geographic area, then one would want to use this information in determining the proper specification. In the absence of any compelling evidence on this matter, we experiment with specifications that allow gun shows to influence mortality in zip codes located within various 
distances of the show itself. In our baseline specification, we allow gun shows to influence mortality within a 10-mile radius of the zip code in which the show took place. In these specifications, the nshowstm1 variable reflects the number of gun shows that took place in week t-1 in zip codes located within 10-miles of zip code $z$, where we calculate distance from the centroid of each zip code. Note that the unit of observation for these regressions is still the zip code*week, and the outcome still measures the number of deaths in zip code $z$ in week $t$.

We then present results for 5-mile and 25-mile radii along with results limiting the impact of gun shows to the zip code of the show itself. It is worth noting that, unlike the other sensitivity analyses we present, the results from these alternative specifications of distance to show will not provide a "falsification test" for our baseline model. While we have some intuition that a gun show in one zip code will likely influence mortality in neighboring zip codes, we have no reason to believe that effects we find within, say, a 25-mile radius are "better" than the effects within a 10-mile radius. Instead, one should view this exercise as identifying where potential effects may exist.

\section{Estimation}

Throughout the analysis, our outcome will be some measure of the number of gun-related deaths in a particular location at a particular time. However, the choice of the correct specification depends in large part on the way in which one believes that gun shows influence gun-related deaths. If one believes that a gun show will reduce the "shadow price" of purchasing a gun by the same amount for all individuals in each location, then (all else equal) one might expect the impact of the gun show to be proportional to the population in the relevant jurisdiction. For example, a gun show that takes place in a town of 10,000 people might allow 
the one person who is contemplating suicide sufficiently easy access to a firearm to induce her to kill herself, resulting in one additional gun death. In an otherwise comparable town of 100,000 people, one would expect there to be 10 such individuals who might be induced to commit suicide by the "gun show-induced" availability of a firearm. This type of proportional effect suggests a specification in which the outcome is measured per capita (e.g, deaths per 100,000 residents), or is measured relative to the average number of deaths in the location. ${ }^{14}$

On the other hand, if one believes that gun shows will have a similar impact on the number of deaths across locations regardless of population, one could estimate a simple OLS model using the number of gun deaths in a particular location*week as the outcome. This specification would be reasonable if one believed that the gun shows induce a smaller change in gun availability (i.e., a smaller price reduction) for the average person in larger geographic areas because transportation costs limit the access to gun shows in large areas, or perhaps because there are already many alternative ways to obtain a firearm without going through standard background checks in larger areas. If the supply of guns available at gun shows is limited relative to the demand, this might also be a reason that the effect is not proportional to the population.

Because we believe that the effects of gun shows are likely to be only partially proportional to the population size, we estimate several different specifications. To begin, we estimate a straightforward OLS model where the outcome is the number of deaths. ${ }^{15}$ In addition, we estimate negative binomial and Poisson regression models. In these models, the mean number of deaths $(\mu)$ is modeled as an exponential function of the predictors (i.e., $\mu=e^{x \beta}$ ), so that the

\footnotetext{
${ }^{14}$ To the extent that the total population is highly correlated with the number of gun-related deaths in a jurisdiction, models that estimate proportional effects relative to a population base will be quite similar to those that use the number of deaths as the base.

${ }^{15}$ This model will suffer from extreme heteroskedasticity given the variation in zip code size. Because we present cluster-robust standard errors (clustering by zip code), our standard errors will be consistent, but not efficient.
} 
resulting estimates reflect the proportional effect of gun shows. Specifically, the exponentiated coefficients from these models can be interpreted as incidence rate ratios, which reflect the percent effect of gun shows on the number of deaths in a zip code. ${ }^{16}$ Both the negative binomial and Poisson regressions are consistent under our identifying assumptions. The negative binomial is a generalization of the Poisson regression model that allows for the variance of the outcome measure to differ from the mean. This technique is ideal for dealing with count data with overdispersion since it provides more efficient estimates than Poisson regression. In order to accommodate the zip code-year fixed effects in our model, we use the fixed effects negative binomial model developed by Hausman, Hall, and Griliches (1984). However, Allison and Waterman (2002) have shown that this model is not a true fixed effects estimator in the sense that it does not necessarily control for all stable unit-specific covariates as does the standard linear fixed effect model. Thus, we present estimates from a fixed effects Poisson regression, which does provide consistent estimates in the presence of time-invariant unit-specific confounding factors.

In all models, we will account for possible serial correlation within jurisdictions and other forms of heteroskedasticity. In the OLS models, we estimated Eiker-White standard errors that are clustered by zip code. In the negative binomial and Poisson models, we use a block bootstrap where the blocking variable is the zip code.

\footnotetext{
${ }^{16}$ One might also estimate models with a binary outcome indicating whether the location experienced at least one gun-related death in a given week. This approach may attenuate any effects of gun shows, however. The reason for this is that large jurisdictions almost always experience at least one death and, conversely, small jurisdictions almost never experience a death. This will tend to bias the coefficients on our gun show indicators toward zero. To see this, consider a large jurisdiction such as Los Angeles that has at least one gun death every week. Here the coefficient on our gun show measures will be zero by construction. The same will be true for jurisdictions where no gun-deaths occur.
} 


\section{Results}

In this section, we present our findings. The first subsection describes our main or baseline results. The next subsection presents a series of sensitivity analyses. The final subsection explores the heterogeneity of the effects.

\section{$\underline{\text { Main Results }}$}

Table 3 presents our main results that focus on the set of zip codes that have at least one gun show within a 10-mile radius over the entire sample period, which includes roughly 53 and 33 percent of zip codes in California and Texas, respectively. Each column reflects a separate regression following equation (1) in the section above. In addition to the gun show variables shown in the table, all models include zip code*year and month fixed effects, and the standard errors are clustered by zip code. Results are shown for gun homicides and suicides as well as the number of non-gun homicides and suicides. This allows us to explore whether the increase in gun availability due to gun shows shifted the mode of homicide and suicide, but not necessarily the total number of deaths.

Looking first at the California results, we see only limited evidence of any effect, and the significant effects we do find are relatively modest in size. There are no statistically or economically significant effects for any of the outcomes in either the week of the show or the two to three weeks following a show. However, there is some evidence of an interesting substitution pattern in the first week following the week of a gun show. For both homicides and suicides, gun deaths seem to increase slightly while non-gun deaths decrease slightly 8 to 14 days following a gun show. This pattern is strongest for suicide. Gun suicides increase by .0023 in the second week after a gun show. Given the baseline mean of .025, this represents an 
increase of roughly 10 percent. At the same time, non-gun suicides decrease by exactly the same absolute amount (.0023). ${ }^{17}$ As mentioned previously, a 10-day waiting period upon the purchase of a firearm exists in California. Thus, consistent with our results, one would not expect to find any significant change in gun deaths until at least the week following the show. In fact, a number of studies indicate that suicides occur most frequently on Mondays for both males and females and most age groups (Maldonado and Kraus, 1991; Lester; 1979). If we assume that the typical gun show purchase occurs on Saturday, then the 10th day occurs on the following Monday, which is included in our first week after the show variable.

The point estimates for gun and non-gun homicides display the same pattern, but are smaller in both absolute and relative magnitude. In fact, the point estimate of .0012 on gun homicides is not significant at conventional levels. Moreover, these estimates are reasonably precise. The confidence interval on the second week gun homicide result ranges from approximately -.0018 to .0042 . Given the baseline mean of .035 , this estimate allows us to rule out an increase in gun homicides of more than 12 percent. ${ }^{18}$

In Texas, the effects of gun shows appear quite different. We find a sharp decline in the number of gun-homicides in the weeks immediately following a gun show. The one- and twoweek estimates suggest reductions of about .0022 deaths in each week, roughly 20 percent of the sample mean. It is not clear what might be driving these seemingly "perverse" results. One potential explanation is that local police are more vigilant in the weeks immediately following gun shows. While not statistically significant, the negative point estimates for non-gun

\footnotetext{
${ }^{17}$ While not significant at conventional levels, it is worth noting that the point estimate for the week following a show in the gun suicide model is -.0019, roughly equivalent in magnitude and opposite in sign as the two-week effect. Taken together, these results suggest that gun shows would not change the number of gun suicides in the first two weeks following a show.

${ }^{18}$ It is important to keep in mind that this second week gun homicide coefficient captures the effect 8 to 14 days following a gun show. Yet, because homicides occur most frequently over the weekend, the peak homicide period during this 8 to 14 day period likely occurs before the 10-day waiting period is over. Of course, it is possible that criminals waiting for a gun use that gun upon receiving it, regardless of whether it is a weekday or weekend.
} 
homicides in this sample are consistent with this hypothesis. Alternatively, criminals (or potential criminals) might use gun shows as an opportunity to sell their weapons, thus reducing their ability to commit gun crimes in the short-run. Unlike California, we find no evidence that gun shows in Texas influence gun or non-gun suicide rates.

Table 4 explores the sensitivity of our results to the size of the geographic area in which we allow gun shows to have an impact. In our baseline specification, we allow gun shows to influence mortality in any zip code located within a 10-mile radius of the zip code in which the gun show took place. Here we show results for three alternative specifications: (i) gun shows that take place only within the actual zip code in which mortality is measured; (ii) gun shows that take place within a 5-mile radius of the zip code in which mortality is measured, and (iii) gun shows that take place within a 25-mile radius of the zip code in which mortality is measured. It is important to note that the sample that provides the identifying variation differs across specifications.

Columns 1-4 show results that focus only on gun shows that take place in the same zip code in which mortality is measured. Because we limit our analysis to only those zip codes with at least one gun show during the sample period, our sample here includes less than 10 percent of all zip codes (98 out of 1,664 zip codes in California and 120 out of 1,861 zip codes in Texas). In Texas, the "perverse" increase in homicides following gun shows disappears, and there is a significant and positive effect on gun suicides in the week following a gun show. In California, the week two substitution from non-gun to gun deaths is no longer apparent, and gun shows do not appear to have any consistent impacts on gun homicides or suicides. Columns 5-8 show the results using a 5-mile radius. These results are similar to our baseline (10-mile radius) results, 
though somewhat less dramatic. Finally, columns 9-12 show results using a 25-mile radius, which indicate no significant effects.

These results suggest that the impact of gun shows extends beyond the immediate vicinity in which the shows take place, but is limited to regions within 25 miles of the show. As mentioned above, the results based on different geographic “catchment areas" should not be thought of as specification checks per se, but rather as an exploration of the nature and scope of potential impacts.

Perhaps most importantly, regardless of how one prioritizes the different specifications presented above, we find no evidence that gun shows have substantial impacts on either gun homicides or gun suicides. For example, in our estimates for the state of California that use a ten-mile radius, we estimate that gun shows lead to an additional four gun suicides in the average year, with this offset by an almost identical decline in the number of non-gun suicides. Additionally, in the analogous specifications for Texas, we estimate that gun shows reduce the number of gun homicides by 16 in the average year, with this representing just one percent of all homicides in the state.

For the remainder of the paper, we focus on specifications that allow gun shows to influence mortality in zip codes within a 10-mile radius of the zip code in which the show occurred. Results using alternative geographic areas are available from the authors upon request.

\section{$\underline{\text { Sensitivity Analyses }}$}

In the preceding analysis, we use high frequency variation within jurisdictions to isolate the causal impact of gun shows from other factors that may be correlated with the presence of gun shows and with mortality rates. Table 5 shows estimates derived from the model shown in 
equation (2), which includes indicators that allow us to examine whether there is any change in death rates leading up to a gun show. Recall that this specification not only allows us to explore temporal substitution, but also serves as a specification check against contemporaneous events that might influence death rates and lead us to find a spurious correlation between gun shows and mortality. Surveying the estimates in this table, we see no systematic evidence of changes in death rates leading up to a gun show.

Table 6 explores whether the results above are sensitive to the model specification. Column 1 reproduces the baseline results for gun homicides from Table 3. Column 2 shows estimates that are weighted by the total population in the zip code (from the 2000 census). The results are extremely similar to the unweighted estimates. Columns 3 and 4 show the exponentiated coefficients (and p-values in parentheses) from negative binomial and Poisson regressions where the outcome is the number of deaths. The sample sizes for these regressions are smaller than the baseline because these models are estimated off of the set of observations for which there is at least one gun death in a given zip*year. Column 5 shows the OLS estimates for this same sample to allow one to distinguish between differences due to sample size and those due to model specification. Columns 6 through 10 present parallel specifications for gun suicides. While the magnitude of the Poisson and Negative Binomial estimates are somewhat smaller than the OLS estimates in several specifications (e.g., gun homicides in TX in week 1), the basic pattern of results - both magnitude and significance - is comparable across specifications.

Table 7 explores the robustness of our results to alternative controls for unobservable factors, which might lead to spurious correlations. In our baseline specification, we include zip code*year and month fixed effects. In this table, we present results from three alternative sets of 
fixed effects: separate main effects for month, year and zip code; separate main effects for week defined over the entire sample period (i.e., 1-569) and zip code; and week-of-year (i.e., 1-52) and zip code*year. The results do not change appreciably across any of these alternative specifications.

\section{Heterogeneous Effects}

Table 8 estimates our baseline specification separately for zip codes defined in terms of poverty and urbanicity. We consider three mutually exclusive (and collectively exhaustive) groups: (1) zips in which at least 30 percent of the population is living in a rural area (as defined by the census); (2) zips in which less than 30 percent are living in a rural area and fewer than 10 percent are below the poverty line; and (3) zips where fewer than 30 percent are living in a rural area but at least 10 percent are in poverty. These groups are meant to roughly capture rural, urban non-poor and urban poor areas. Results are not sensitive to moderate changes in the definition of these groups. We find that the "perverse" gun-homicide effects in Texas are driven by gun shows in or near higher-poverty, urban areas; there is no effect (positive or negative) in the other zip code types. The suicide effects in California appear in both the higher and lowerpoverty non-rural areas.

Our sample spans 11 years, during which there were substantial economic and political changes, along with corresponding changes in national crime statistics. For example, from 1994 to 1999, the number of homicides in the U.S. decreased by more than 33\%; from 1999 to 2004, the annual number of homicides began to slowly increase. As mentioned previously and shown in Figure 2, similar patterns are seen in the annual number of gun deaths in Texas and California. Gun deaths are decreasing until 1999 in California and 2000 in Texas. For this reason, we 
estimate our models separately for the six-year period from 1994-1999 and the five-year period from 2000-2004. The results, shown in Table 9, suggest that the majority of the perverse Texas homicide effect is coming from the second half of our sample period whereas the significant California results come from the first half of our sample period. One possible explanation of this finding in California is the enactment of the "nation's broadest legislation to increase oversight at gun shows” in California in 1999, which specified that gun show promoters must obtain a certificate of eligibility from the state Department of Justice following a background check (LCAV, 2008). ${ }^{19}$

To the extent that gun shows influence homicide and suicide rates by increasing the availability of guns, one might think that the effects would be smaller in locations where guns are more readily available. While we do not have any direct measures of gun ownership, following Azrael, Cook, and Miller (2004), we use the fraction of suicides committed with a gun as a proxy for gun ownership. Specifically, Table 10 shows models in which we interact each of the gun show variables with the fraction of suicides committed with a gun in the zip code over the entire sample period. We de-mean the fraction gun suicide so that the main effects of the gun show variables reflect the impact at the sample mean. Note that the sample sizes are slightly smaller than in our baseline specifications because we exclude zip codes that did not experience any suicides over the entire sample period. For California, none of these interactions are statistically significant. In Texas, however, the interactions for the gun homicide outcomes (column 5) are negative, indicating that in zip codes with high gun ownership, gun shows are associated with even greater reductions in gun-related homicides than in zip codes with lower

\footnotetext{
${ }^{19}$ This legislation also required that promoters: “(i) prepare security plans for gun shows and notify state and local law enforcement of those plans, (ii) certify that they will comply with all applicable federal, state, and local laws, (iii) obtain liability insurance in an amount not less than $\$ 1$ million, (iv) ensure that all firearms brought into the shows are cleared of ammunition and tagged for identification purposes, and (v) prohibit anyone under age 18 from entering unless accompanied by a parent, grandparent, or legal guardian" (LCAV, 2008).
} 
gun ownership. In order to explore whether this interaction is driven by the predominantly rural zip codes, the specification in column 6 includes a second set of interactions between the gun show variables and the percent of the zip code population living in a rural area. The gun suicide results remain negative and significant. One explanation for this finding is that the police response to gun shows is even greater in localities with already high gun ownership.

\section{Conclusion}

Thousands of gun shows take place in the U.S. every year. Gun control advocates argue that the "gun show loophole" that exists in many states makes it easier for potential criminals to obtain a gun. Gun shows may also affect suicide rates by increasing the ease with which individuals who are contemplating suicide can obtain a more lethal device. On the other hand, opponents of gun show regulations argue that gun shows are innocuous because potential criminals and other individuals can acquire guns easily through other channels.

In this paper, we have investigated the effect of gun shows using eleven years of data on the date and location of every gun show in the states of California and Texas, the nation's two most populous states. We have combined this with information on the date, location, and cause of every death occurring in these same two states during our eleven-year study period. We focus our attention on homicides and suicides, with firearms accounting for 61 percent of the combined 106,205 deaths from these two causes in California and Texas during the 1994 to 2004 period.

Our identification strategy tests whether the number of homicides or suicides changes in the weeks immediately following a gun show. We investigate separate models for the two states given that they sit at opposite ends of the spectrum with respect to their regulation of gun shows, with California arguably the strictest and Texas among the least stringent. To the extent that 
regulations such as those in place in California reduce any deleterious effects of gun shows, one might expect to detect a larger effect in a relatively unregulated state such as Texas.

Our results, however, provide no evidence to suggest that gun shows lead to a substantial increase in the number of homicides or suicides in either California or Texas. If anything, we find evidence of a modest decline in the number of homicides following the average gun show in Texas, though our aggregate implied effects amount to just one percent of all homicides in the state of Texas. Taken together, our results suggest that gun shows do not increase the number of homicides or suicides and that the absence of gun show regulations does not increase the number of gun-related deaths as proponents of these regulations suggest.

There are, however, two important caveats to our analyses. First, we are considering only the effect in the geographic area immediately surrounding gun shows. To the extent that firearms purchased at gun shows are transported more than 25 miles away from the show, our identification strategy will not capture this effect. Additionally, we consider the effect only in the four weeks immediately following a gun show. However, guns are durable, and thus to the extent that effects occur much later, our analysis will not capture this. 


\section{$\underline{\text { References }}$}

Allison, Paul D. and Waterman, Richard P. (2002). "Fixed-Effects Negative Binomial Regression Models.” Sociological Methodology 32(1): 247-265.

Ayres, I. \& Donohue, J. (1999). Nondiscretionary Concealed Weapons Law: A Case Study of Statistics, Standards of Proof, and Public Policy. American Law and Economics Review 1(1): 436-70.

Azrael, D., Cook P., and Miller, M. (2004). State and Local Prevalence of Firearms Ownership Measurement, Structure, and Trends. Journal of Quantitative Criminology 20(1): 43-62.

Azrael, D., Hemenway, D., and Miller, M. (2002). Household Firearm Ownership and Suicide Rates in the United States. Epidemiology 13(5): 517-24.

Black, D. \& Nagin, D. (1998). Do Right-To-Carry Laws Deter Violent Crime? Journal of Legal Studies 27(1): 209-19.

Brady Campaign to Prevent Gun Violence. http://www.bradycampaign.org.

Cook, P.J. (1983). The influence of gun availability on violent crime patterns. Crime and Justice 4: 49-89.

Cook, P.J. \& Ludwig, J. (2004). The social costs of gun ownership. NBER Working Paper 
(August 2004).

Cook, P.J., \& Ludwig, J. (1996). Guns in America: Results of a Comprehensive Survey of Gun Ownership and Use. Washington, D.C.: Police Foundation.

Duggan, M. (2003). Guns and suicide. In Ludwig, J. \& Cook, P.J. (Eds.) Evaluating Gun Policy: Effects on Crime and Violence. Washington, D.C.: Brookings.

Duggan, M. (2001). More guns, more crime. Journal of Political Economy 109(5) (October 2001): 1086-1114).

Gun and Knife Show Calendar. Krause Publications, 1994-2004.

Harlow, C. (2001). Firearm Use by Offenders. Bureau of Justice Statistics, U.S. Department of Justice (November 2001).

Hausman, Jerry, Bronwyn H. Hall, and Zvi Griliches (1984). “Econometric Models for Count Data with an Application to the Patents-R\&D Relationship.” Econometrica 52(4): 909938.

Kellermann, A., Rivara, F., Somes, G., Reay, G., Francisco, J., Banton, J., Prodzinski, J., Fligner, C., \& Hackman, B. (1992). Suicide in the Home in Relation to Gun Ownership. New England Journal of Medicine 327(7): 467-472. 
Kleck, G. (1984). The Relationship between gun ownership levels and rates of violence in the United States.” in Firearms and Violence, edited by D.B. Kates, Jr. Cambridge: Ballinger Publishing Company.

Krouse, W. (2005). Gun Legislation in the $109^{\text {th }}$ Congress. Congressional Research Service Report RL32842, March 31, 2005.

Legal Community Against Violence (2008). Regulating Guns in America: An Evaluation and Comparative Analysis of Federal, State and Selected Local Gun Laws. www.lcav.org,

Lester, D. (1979). Temporal Variation in Suicide and Homicide. American Journal of Epidemiology 109(5): 517-520.

Loftin, C., McDowall, D., Wiersema, B., \& Cottey, T. (1991). Effects of restrictive licensing of handguns on homicide and suicide rates in the District of Columbia. New England Journal of Medicine 325(23): 1615-1620.

Lott, J. (2003). The Bias Against Guns. Washington, D.C.: Regenry.

Lott, J. \& Mustard, D. (1997). Crime, deterrence, and right-to-carry concealed handguns. Journal of Legal Studies 26 (January 1997): 1-68. 
Ludwig, J. \& Cook, P.J. (2000). Homicide and suicide rates associated with implementation of the Brady Handgun Violence Prevention Act. Journal of the American Medical Association 284(5): 585-591.

Maldonado, G. and Kraus, JF. (1991). Variation in Suicide Occurrence by Time of Day, Day of the Week, Month, and Lunar Phase. Suicide Life Threatening Behavior 21(2):174-187.

Moody, C. (2001). Testing for the Effects of Concealed Weapons Laws: Specification Errors and Robustness. Journal of Law and Economics 44(2) Part 2: 799-813.

National Opinion Research Center (1998). 1997-1998 National Gun Policy Survey. University of Chicago (September 1998).

Sloan, J., Rivara, F., Reay, D., Ferris, J., Path, M., \& Kellermann, A. (1990). Firearm regulations and rates of suicide: A comparison of two metropolitan areas. New England Journal of Medicine 322(6): 369-373.

U.S. Department of Justice, Bureau of Justice Statistics (2003a). Background Checks for Firearm Transfers, 2002 (Washington, September 2003).

U.S. Department of Justice, Bureau of Justice Statistics (2003b). Survey of State Procedures Related to Firearm Sales, Midyear 2002 (Washington, October 15, 2003). 
U.S. Department of Justice, Federal Bureau of Investigation (2004). Crime in the United States, 2003 (Washington, October 25, 2004).

U.S. Department of Justice, U.S. Department of the Treasury, Bureau of Alcohol, Tobacco and Firearms (1999). Gun Shows: Brady Checks and Crime Gun Traces (January 1999). Retrieved May 23, 2005 from www.treas.gov/press/releases/report3100.

U.S. Department of the Treasury, Bureau of Alcohol, Tobacco and Firearms (2002). Firearms Commerce in the United States (February 2000). Retrieved May 23, 2005 from http://www.atf.gov.

U.S. Department of the Treasury, Bureau of Alcohol, Tobacco and Firearms (2002). Firearms Commerce in the United States, 2001/2002, ATF P 9000.4 (April 2002). Retrieved May 23, 2005 from http://www.atf.gov.

U.S. Department of the Treasury, Bureau of Alcohol, Tobacco and Firearms (2000). Following the Gun: Enforcing Federal Laws Against Firearms Traffickers. (June 2000). Retrieved May 31, 2005 from http://www.atf.gov.

U.S. Department of the Treasury, Bureau of Alcohol, Tobacco and Firearms (2008). Annual Firearms Manufacturers and Export Report. (2006). Retrieved August 12, 2008 from http://www.atf.gov. 
Virginia Tech Review Panel. (2007). Mass Shootings at Virginia Tech. Report of the Virginia Tech Review Panel presented to Governor Kaine Commonwealth of Virginia. Retrieved on August 13, 2008.

Wintemute, G. (2007). Gun shows across a multistate American gun market: observational evidence of the effects of regulatory policy. Injury Prevention 13, 150-155. 
$\underline{\text { Table1. Weekly Gun-Related Deaths per 100,000 Residents }}$

\begin{tabular}{|c|c|c|c|c|c|c|c|c|}
\hline & \multirow{2}{*}{$\begin{array}{c}\text { All Zip Codes } \\
\text { All Weeks } \\
(1) \\
\end{array}$} & \multicolumn{3}{|c|}{ Zip Codes with 1+ Gun Shows } & \multicolumn{3}{|c|}{$\begin{array}{l}\text { Zip Codes with } 1+\text { Gun Shows within } \\
\text { a } 10 \text { Mile Radius }\end{array}$} & \multirow{2}{*}{$\begin{array}{c}\text { Zip Codes with } \\
\text { no Gun Shows } \\
\text { All Weeks } \\
\text { (8) }\end{array}$} \\
\hline & & $\begin{array}{c}\text { All Weeks } \\
\text { (2) }\end{array}$ & $\begin{array}{c}\text { Gun Show } \\
\text { Weeks } \\
(3) \\
\end{array}$ & $\begin{array}{c}\text { Non Gun } \\
\text { Show Weeks } \\
(4)\end{array}$ & $\begin{array}{c}\text { All Weeks } \\
(5)\end{array}$ & $\begin{array}{c}\text { Gun Show } \\
\text { Weeks } \\
(6)\end{array}$ & $\begin{array}{c}\text { Non Gun } \\
\text { Show Weeks } \\
(7)\end{array}$ & \\
\hline \multicolumn{9}{|l|}{ California Zip Codes } \\
\hline All gun deaths & 0.351 & 0.207 & 0.215 & 0.207 & 0.261 & 0.147 & 0.266 & 0.360 \\
\hline Gun suicides & 0.226 & 0.111 & 0.088 & 0.112 & 0.161 & 0.071 & 0.165 & 0.233 \\
\hline Gun homicides & 0.091 & 0.088 & 0.120 & 0.087 & 0.095 & 0.071 & 0.096 & 0.091 \\
\hline Accidental gun deaths & 0.006 & 0.005 & 0.007 & 0.005 & 0.004 & 0.004 & 0.004 & 0.006 \\
\hline Number of zip codes & 1,664 & 98 & 98 & 98 & 901 & 901 & 901 & 1,566 \\
\hline Number of zipweeks & 941,824 & 55,468 & 1,121 & 54,347 & 509,966 & 20,496 & 489,470 & 886,356 \\
\hline \multicolumn{9}{|l|}{ Texas Zip Codes } \\
\hline All gun deaths & 0.272 & 0.225 & 0.228 & 0.225 & 0.233 & 0.245 & 0.232 & 0.275 \\
\hline Gun suicides & 0.183 & 0.138 & 0.143 & 0.138 & 0.128 & 0.115 & 0.130 & 0.186 \\
\hline Gun homicides & 0.075 & 0.077 & 0.076 & 0.077 & 0.096 & 0.121 & 0.093 & 0.075 \\
\hline Accidental gun deaths & 0.012 & 0.007 & 0.005 & 0.007 & 0.006 & 0.006 & 0.006 & 0.012 \\
\hline Number of zip codes & 1,861 & 120 & 120 & 120 & 695 & 695 & 695 & 1,741 \\
\hline Number of zip*weeks & $1,053,326$ & 67,920 & 1,978 & 65,942 & 393,370 & 39,598 & 353,772 & 985,406 \\
\hline
\end{tabular}

Notes: The cells contain the average number of gun-related deaths per capita for each week in relevant sample. The unit of observation is zip code*week. Population numbers based on the 2000 census. The zip codes in columns (2), (3) and (4) overlap with the zip codes in columns (5), (6) and (7). Specifically, the former are a subset of the latter. 
Table 2. Where Do Gun Shows Take Place? Evidence from California and Texas Zip Codes

\begin{tabular}{|c|c|c|c|c|c|c|c|}
\hline & & \multicolumn{3}{|c|}{ Mean, for Zip Codes with: } & \multicolumn{3}{|c|}{ Mean, for Zip Codes with: } \\
\hline & & $\begin{array}{c}1+\text { Gun } \\
\text { Shows } \\
(1)\end{array}$ & $\begin{array}{c}\text { No Gun } \\
\text { Shows } \\
(2)\end{array}$ & $\begin{array}{c}\text { Difference } \\
(3) \\
\end{array}$ & $\begin{array}{c}\text { 1+ Gun Shows } \\
\text { within } 10 \text { Miles } \\
(4)\end{array}$ & $\begin{array}{c}\text { No Gun Shows } \\
\text { within } 10 \text { Miles } \\
(5)\end{array}$ & $\begin{array}{c}\text { Difference } \\
(6) \\
\end{array}$ \\
\hline \multirow{9}{*}{ California } & Total population & 31,817 & 19,634 & $\begin{array}{c}12182^{\star \star *} \\
(2056)\end{array}$ & 29,418 & 9,646 & $\begin{array}{c}19,772 \text { *** } \\
(871)\end{array}$ \\
\hline & $\begin{array}{l}\text { Population density } \\
\text { (population/sq. mile) }\end{array}$ & 2,930 & 3,193 & $\begin{array}{l}-263 \\
(400)\end{array}$ & 5,356 & 605 & $\begin{array}{c}4,751^{\star \star \star} \\
(220)\end{array}$ \\
\hline & Land area (sq. miles) & 71.2 & 68.2 & $\begin{array}{c}3.0 \\
(10.7)\end{array}$ & 25.9 & 118.5 & $\begin{array}{c}-92.6^{\star \star \star \star} \\
(6.9)\end{array}$ \\
\hline & Fraction rural & 0.12 & 0.36 & $\begin{array}{c}-0.242^{\star \star \star} \\
(0.025)\end{array}$ & 0.11 & 0.63 & $\begin{array}{c}-0.519^{\star \star \star} \\
(0.018)\end{array}$ \\
\hline & Fraction Hispanic & 0.28 & 0.24 & $\begin{array}{l}0.044^{\star *} \\
(0.021)\end{array}$ & 0.27 & 0.21 & $\begin{array}{c}0.062^{\star \star \star} \\
(0.011)\end{array}$ \\
\hline & Fraction Black & 0.06 & 0.04 & $\begin{array}{c}0.015^{\star} \\
(0.008)\end{array}$ & 0.06 & 0.02 & $\begin{array}{c}0.045^{\star \star *} \\
(0.004)\end{array}$ \\
\hline & Fraction below poverty line & 0.15 & 0.14 & $\begin{array}{c}0.009 \\
(0.009)\end{array}$ & 0.13 & 0.15 & $\begin{array}{c}-0.016^{\star \star *} \\
(0.004)\end{array}$ \\
\hline & Zip is in an MSA & 0.84 & 0.83 & $\begin{array}{c}0.008 \\
(0.039)\end{array}$ & 0.94 & 0.70 & $\begin{array}{c}0.239 * * * \\
(0.018)\end{array}$ \\
\hline & Fraction of suicides by gun & 0.49 & 0.53 & $\begin{array}{l}-0.042^{\star *} \\
(0.017)\end{array}$ & 0.48 & 0.60 & $\begin{array}{c}-0.123^{\star * \star} \\
(0.013)\end{array}$ \\
\hline \multirow{9}{*}{ Texas } & Total population & 23,429 & 10,358 & $\begin{array}{c}13,071^{\star \star \star} \\
(1493)\end{array}$ & 20,948 & 5,391 & $\begin{array}{l}15,558^{\star \star \star} \\
(646)\end{array}$ \\
\hline & $\begin{array}{l}\text { Population density } \\
\text { (population/sq. mile) }\end{array}$ & 1,088 & 869 & $\begin{array}{c}218 \\
(149)\end{array}$ & 2,114 & 150 & $\begin{array}{c}1,964^{\star * \star} \\
(111)\end{array}$ \\
\hline & Land area (sq. miles) & 222.8 & 110.9 & $\begin{array}{c}111.9 * * * \\
(35.3)\end{array}$ & 63.8 & 150.4 & $\begin{array}{c}-86.6^{\star \star \star} \\
(9.4)\end{array}$ \\
\hline & Fraction rural & 0.22 & 0.60 & $\begin{array}{c}-0.375^{\star \star \star} \\
(0.026)\end{array}$ & 0.19 & 0.80 & $\begin{array}{c}-0.604^{\star \star \star} \\
(0.016)\end{array}$ \\
\hline & Fraction Hispanic & 0.31 & 0.24 & $\begin{array}{c}0.067^{\star * *} \\
(0.023)\end{array}$ & 0.29 & 0.22 & $\begin{array}{c}0.076^{\star \star *} \\
(0.012)\end{array}$ \\
\hline & Fraction Black & 0.11 & 0.08 & $\begin{array}{l}0.027^{\star *} \\
(0.012)\end{array}$ & 0.12 & 0.06 & $\begin{array}{c}0.060^{\star \star *} \\
(0.007)\end{array}$ \\
\hline & Fraction below poverty line & 0.18 & 0.15 & $\begin{array}{l}0.033^{\star \star \star} \\
(0.009)\end{array}$ & 0.14 & 0.15 & $\begin{array}{l}-0.012^{\star \star} \\
(0.005)\end{array}$ \\
\hline & Zip is in an MSA & 0.62 & 0.53 & $\begin{array}{l}0.085^{\star} \\
(0.046)\end{array}$ & 0.88 & 0.33 & $\begin{array}{l}0.542^{\star * \star} \\
(0.019)\end{array}$ \\
\hline & Fraction of suicides by gun & 0.62 & 0.66 & $\begin{array}{c}-0.036^{\star *} \\
(0.018)\end{array}$ & 0.61 & 0.70 & $\begin{array}{c}-0.090^{\star * *} \\
(0.012)\end{array}$ \\
\hline
\end{tabular}

Notes: Each cell in the 1st, 2nd, 4th and 5th columns contains the mean of the row variable for the sample indicated by the column header. The 3rd and 6th columns give the difference by regressing the row variable on the "whether there was a gun show" dummy. The unit of observation is zip code*week. There are fewer observations for "fraction of suicides by gun" because this variable is missing for those zips that had zero suicides from 1994 to 2004 . *significant at $10 \%$; ${ }^{* *}$ significant at $5 \%$; ${ }^{\star \star \star}$ significant at $1 \%$. 
Table 3. OLS, Gun and Non-Gun Homicides and Suicides

\begin{tabular}{|c|c|c|c|c|c|}
\hline & & \multicolumn{4}{|c|}{ Within 10 Mile Radius } \\
\hline & & \multicolumn{2}{|c|}{ Homicides } & \multicolumn{2}{|c|}{ Suicides } \\
\hline & & Gun & Non-Gun & Gun & Non-Gun \\
\hline \multirow{8}{*}{ California } & Week of Show & $\begin{array}{l}-0.0007 \\
(0.0012)\end{array}$ & $\begin{array}{c}0.0001 \\
(0.0008)\end{array}$ & $\begin{array}{c}-0.0019 \\
(0.0012)\end{array}$ & $\begin{array}{c}0.0001 \\
(0.0012)\end{array}$ \\
\hline & 1st Week Post-Show & $\begin{array}{c}0.0012 \\
(0.0015)\end{array}$ & $\begin{array}{c}-0.0015^{\star \star} \\
(0.0007)\end{array}$ & $\begin{array}{c}0.0023^{*} \\
(0.0012)\end{array}$ & $\begin{array}{l}-0.0023^{*} \\
(0.0013)\end{array}$ \\
\hline & 2-3 Weeks Post-Show & $\begin{array}{c}0.0001 \\
(0.0009)\end{array}$ & $\begin{array}{c}0.0007 \\
(0.0006)\end{array}$ & $\begin{array}{c}0.0001 \\
(0.0008)\end{array}$ & $\begin{array}{l}-0.0007 \\
(0.0009)\end{array}$ \\
\hline & Observations (zip*weeks) & 509,966 & 509,966 & 509,966 & 509,966 \\
\hline & Number of zip codes & 901 & 901 & 901 & 901 \\
\hline & R-squared & 0.121 & 0.033 & 0.033 & 0.034 \\
\hline & Mean (dependent var) & 0.035 & 0.013 & 0.025 & 0.028 \\
\hline & Std. Dev (dependent var) & 0.203 & 0.117 & 0.159 & 0.176 \\
\hline \multirow{11}{*}{ Texas } & & \multicolumn{4}{|c|}{ Within 10 Mile Radius } \\
\hline & & \multicolumn{2}{|c|}{ Homicides } & \multicolumn{2}{|c|}{ Suicides } \\
\hline & & Gun & Non-Gun & Gun & Non-Gun \\
\hline & Week of Show & $\begin{array}{c}-0.0022^{\star *} \\
(0.0010)\end{array}$ & $\begin{array}{l}-0.0003 \\
(0.0006)\end{array}$ & $\begin{array}{c}0.0001 \\
(0.0009)\end{array}$ & $\begin{array}{c}-0.0012 \\
(0.0008)\end{array}$ \\
\hline & 1st Week Post-Show & $\begin{array}{c}-0.0023^{\star \star} \\
(0.0010)\end{array}$ & $\begin{array}{l}-0.0012 \\
(0.0007)\end{array}$ & $\begin{array}{l}-0.0005 \\
(0.0009)\end{array}$ & $\begin{array}{l}-0.0007 \\
(0.0008)\end{array}$ \\
\hline & 2-3 Weeks Post-Show & $\begin{array}{l}-0.0012 \\
(0.0008)\end{array}$ & $\begin{array}{c}0.0001 \\
(0.0006)\end{array}$ & $\begin{array}{c}0.0000 \\
(0.0007)\end{array}$ & $\begin{array}{l}-0.0004 \\
(0.0006)\end{array}$ \\
\hline & Observations (zip*weeks) & 393,370 & 393,370 & 393,370 & 393,370 \\
\hline & Number of zip codes & 695 & 695 & 695 & 695 \\
\hline & R-squared & 0.065 & 0.031 & 0.033 & 0.030 \\
\hline & Mean (dependent var) & 0.021 & 0.011 & 0.024 & 0.016 \\
\hline & Std. Dev (dependent var) & 0.153 & 0.108 & 0.158 & 0.127 \\
\hline
\end{tabular}

Notes: The sample for all regressions is zip codes that have at least one gun show within a 10 mile radius during the sample period. The week of show, 1st week and 2-3 week lags indicate the number of gun shows within a 10 mile radius. The unit of observation is zip code*week. Standard errors (in parenthesis) are clustered by zip code. Uses month and zip code*year fixed effects. * significant at 10\%; **significant at 5\%; *** significant at $1 \%$. 


\begin{tabular}{|c|c|c|c|c|c|c|c|c|c|c|c|c|c|}
\hline & & \multicolumn{4}{|c|}{ Within Zip Code } & \multicolumn{4}{|c|}{ Within 5 Mile Radius } & \multicolumn{4}{|c|}{ Within 25 Mile Radius } \\
\hline & & \multicolumn{2}{|c|}{ Homicides } & \multicolumn{2}{|c|}{ Suicides } & \multicolumn{2}{|c|}{ Homicides } & \multicolumn{2}{|c|}{ Suicides } & \multicolumn{2}{|c|}{ Homicides } & \multicolumn{2}{|c|}{ Suicides } \\
\hline & & $\begin{array}{l}\text { Gun } \\
(1)\end{array}$ & $\begin{array}{l}\text { Non-Gun } \\
\text { (2) }\end{array}$ & $\begin{array}{l}\text { Gun } \\
\text { (3) }\end{array}$ & $\begin{array}{l}\text { Non-Gun } \\
\text { (4) }\end{array}$ & $\begin{array}{l}\text { Gun } \\
(5)\end{array}$ & $\begin{array}{l}\text { Non-Gun } \\
\text { (6) }\end{array}$ & $\begin{array}{l}\text { Gun } \\
(7)\end{array}$ & $\begin{array}{l}\text { Non-Gun } \\
\text { (8) }\end{array}$ & $\begin{array}{l}\text { Gun } \\
(9)\end{array}$ & $\begin{array}{l}\text { Non-Gun } \\
(10)\end{array}$ & $\begin{array}{l}\text { Gun } \\
\text { (11) }\end{array}$ & $\begin{array}{l}\text { Non-Gun } \\
\text { (12) }\end{array}$ \\
\hline & Week of Show & $\begin{array}{c}0.0092 \\
(0.0064)\end{array}$ & $\begin{array}{l}-0.0025 \\
(0.0038)\end{array}$ & $\begin{array}{l}-0.0045 \\
(0.0062)\end{array}$ & $\begin{array}{c}-0.0112^{\star *} \\
(0.0046)\end{array}$ & $\begin{array}{c}0.0019 \\
(0.0020)\end{array}$ & $\begin{array}{c}0.0026^{*} \\
(0.0014)\end{array}$ & $\begin{array}{l}-0.0004 \\
(0.0018)\end{array}$ & $\begin{array}{l}-0.0004 \\
(0.0020)\end{array}$ & $\begin{array}{l}-0.0005 \\
(0.0006)\end{array}$ & $\begin{array}{c}0.0001 \\
(0.0004)\end{array}$ & $\begin{array}{l}-0.0002 \\
(0.0006)\end{array}$ & $\begin{array}{l}-0.0008 \\
(0.0006)\end{array}$ \\
\hline \multirow[t]{7}{*}{ California } & 1st Week Post-Show & $\begin{array}{c}0.0039 \\
(0.0085)\end{array}$ & $\begin{array}{l}-0.0060^{*} \\
(0.0031)\end{array}$ & $\begin{array}{c}0.0035 \\
(0.0058)\end{array}$ & $\begin{array}{c}0.0041 \\
(0.0058)\end{array}$ & $\begin{array}{c}0.0022 \\
(0.0025)\end{array}$ & $\begin{array}{l}-0.0019 \\
(0.0013)\end{array}$ & $\begin{array}{l}0.0037^{\star} \\
(0.0020)\end{array}$ & $\begin{array}{l}-0.0049^{* *} \\
(0.0021)\end{array}$ & $\begin{array}{c}0.0005 \\
(0.0007)\end{array}$ & $\begin{array}{c}-0.0004 \\
(0.0004)\end{array}$ & $\begin{array}{c}0.0009 \\
(0.0006)\end{array}$ & $\begin{array}{c}-0.0008 \\
(0.0006)\end{array}$ \\
\hline & 2-3 Weeks Post-Show & $\begin{array}{c}-0.0023 \\
(0.0052)\end{array}$ & $\begin{array}{c}0.0046^{*} \\
(0.0027)\end{array}$ & $\begin{array}{c}0.0007 \\
(0.0044)\end{array}$ & $\begin{array}{l}-0.0034 \\
(0.0041)\end{array}$ & $\begin{array}{l}-0.0006 \\
(0.0016)\end{array}$ & $\begin{array}{c}0.0029 * \star \star \\
(0.0011)\end{array}$ & $\begin{array}{c}0.0003 \\
(0.0014)\end{array}$ & $\begin{array}{l}-0.0002 \\
(0.0016)\end{array}$ & $\begin{array}{c}-0.0005 \\
(0.0005)\end{array}$ & $\begin{array}{c}0.0004 \\
(0.0003)\end{array}$ & $\begin{array}{c}0.0005 \\
(0.0004)\end{array}$ & $\begin{array}{l}-0.0006 \\
(0.0005)\end{array}$ \\
\hline & Observations (zip*weeks) & 55,468 & 55,468 & 55,468 & 55,468 & 271,680 & 271,680 & 271,680 & 271,680 & 783,344 & 783,344 & 783,344 & 783,344 \\
\hline & Number of zip codes & 98 & 98 & 98 & 98 & 480 & 480 & 480 & 480 & 1,384 & 1,384 & 1,384 & 1,384 \\
\hline & R-squared & 0.065 & 0.029 & 0.031 & 0.032 & 0.115 & 0.031 & 0.030 & 0.032 & 0.120 & 0.034 & 0.035 & 0.037 \\
\hline & Mean (dependent var) & 0.030 & 0.015 & 0.032 & 0.033 & 0.039 & 0.015 & 0.028 & 0.032 & 0.025 & 0.010 & 0.021 & 0.022 \\
\hline & Std. Dev (dependent var) & 0.184 & 0.129 & 0.179 & 0.183 & 0.214 & 0.125 & 0.168 & 0.179 & 0.174 & 0.102 & 0.145 & 0.157 \\
\hline \multirow{11}{*}{ Texas } & & \multicolumn{4}{|c|}{ Within Zip Code } & \multicolumn{4}{|c|}{ Within 5 Mile Radius } & \multicolumn{4}{|c|}{ Within 25 Mile Radius } \\
\hline & & \multicolumn{2}{|c|}{ Homicides } & \multicolumn{2}{|c|}{ Suicides } & \multicolumn{2}{|c|}{ Homicides } & \multicolumn{2}{|c|}{ Suicides } & \multicolumn{2}{|c|}{ Homicides } & \multicolumn{2}{|c|}{ Suicides } \\
\hline & & Gun & Non-Gun & Gun & Non-Gun & Gun & Non-Gun & Gun & Non-Gun & Gun & Non-Gun & Gun & Non-Gun \\
\hline & Week of Show & $\begin{array}{c}0.0003 \\
(0.0042)\end{array}$ & $\begin{array}{l}-0.0005 \\
(0.0023)\end{array}$ & $\begin{array}{l}0.0077^{\star \star} \\
(0.0039)\end{array}$ & $\begin{array}{c}0.0007 \\
(0.0030)\end{array}$ & $\begin{array}{l}-0.0029^{*} \\
(0.0017)\end{array}$ & $\begin{array}{l}-0.0001 \\
(0.0010)\end{array}$ & $\begin{array}{c}0.0006 \\
(0.0014)\end{array}$ & $\begin{array}{l}-0.0008 \\
(0.0012)\end{array}$ & $\begin{array}{c}-0.0013^{\star \star} \\
(0.0006)\end{array}$ & $\begin{array}{c}0.0004 \\
(0.0004)\end{array}$ & $\begin{array}{l}-0.0005 \\
(0.0005)\end{array}$ & $\begin{array}{c}-0.0003 \\
(0.0004)\end{array}$ \\
\hline & 1st Week Post-Show & $\begin{array}{c}-0.0041 \\
(0.0032)\end{array}$ & $\begin{array}{c}0.0016 \\
(0.0031)\end{array}$ & $\begin{array}{c}0.0008 \\
(0.0046)\end{array}$ & $\begin{array}{l}-0.0043 \\
(0.0034)\end{array}$ & $\begin{array}{c}-0.0022 \\
(0.0017)\end{array}$ & $\begin{array}{c}0.0002 \\
(0.0012)\end{array}$ & $\begin{array}{l}-0.0005 \\
(0.0015)\end{array}$ & $\begin{array}{c}-0.0002 \\
(0.0013)\end{array}$ & $\begin{array}{l}-0.0010^{*} \\
(0.0006)\end{array}$ & $\begin{array}{l}-0.0004 \\
(0.0004)\end{array}$ & $\begin{array}{c}-0.0010^{\star *} \\
(0.0005)\end{array}$ & $\begin{array}{l}-0.0003 \\
(0.0004)\end{array}$ \\
\hline & 2-3 Weeks Post-Show & $\begin{array}{c}0.0024 \\
(0.0025)\end{array}$ & $\begin{array}{c}0.0057^{\star} \\
(0.0029)\end{array}$ & $\begin{array}{c}0.0013 \\
(0.0031)\end{array}$ & $\begin{array}{l}-0.0008 \\
(0.0024)\end{array}$ & $\begin{array}{l}-0.0014 \\
(0.0012)\end{array}$ & $\begin{array}{c}0.0019^{*} \\
(0.0011)\end{array}$ & $\begin{array}{c}0.0012 \\
(0.0013)\end{array}$ & $\begin{array}{c}-0.0011 \\
(0.0010)\end{array}$ & $\begin{array}{c}-0.0001 \\
(0.0004)\end{array}$ & $\begin{array}{l}-0.0000 \\
(0.0003)\end{array}$ & $\begin{array}{c}-0.0009^{* *} \\
(0.0004)\end{array}$ & $\begin{array}{l}-0.0002 \\
(0.0003)\end{array}$ \\
\hline & Observations (zipweeks) & 67,920 & 6,7920 & 67,920 & 67,920 & 201,496 & 201,496 & 201,496 & 201,496 & 800,890 & 800,890 & 800,890 & 800,890 \\
\hline & Number of zip codes & 120 & 120 & 120 & 120 & 356 & 356 & 356 & 356 & 1,415 & 1,415 & 1,415 & 1,415 \\
\hline & R-squared & 0.041 & 0.025 & 0.032 & 0.028 & 0.066 & 0.030 & 0.032 & 0.029 & 0.064 & 0.033 & 0.037 & 0.033 \\
\hline & Mean (dependent var) & 0.017 & 0.011 & 0.031 & 0.018 & 0.024 & 0.013 & 0.027 & 0.018 & 0.012 & 0.007 & 0.016 & 0.010 \\
\hline & Std. Dev (dependent var) & 0.136 & 0.111 & 0.177 & 0.135 & 0.165 & 0.117 & 0.165 & 0.134 & 0.118 & 0.084 & 0.129 & 0.102 \\
\hline
\end{tabular}

Notes: The sample for columns (1) through (4) is zip codes that have at least one gun show during the sample period. For columns (5) through (8) it is zip codes that have at least one gun show within a 5 mile radius during the sample period. And for columns (9) through (12) it is zip codes that have at least one gun show within a 25 mile radius during the sample period. The week of show, 1 st week and 2-3 week lags indicate the number of gun shows within zip code, within a 5 mile radius, and within a 25 mile radius for the respective samples. The unit of observation is zip code*week. Standard errors (in parenthesis) are clustered by zip code. Uses month and zip code*year fixed effects.

* significant at $10 \%$; **significant at $5 \% ;{ }^{* * *}$ significant at $1 \%$. 
Table 5. Robustness Checks, By State, Within 10 Mile Radius

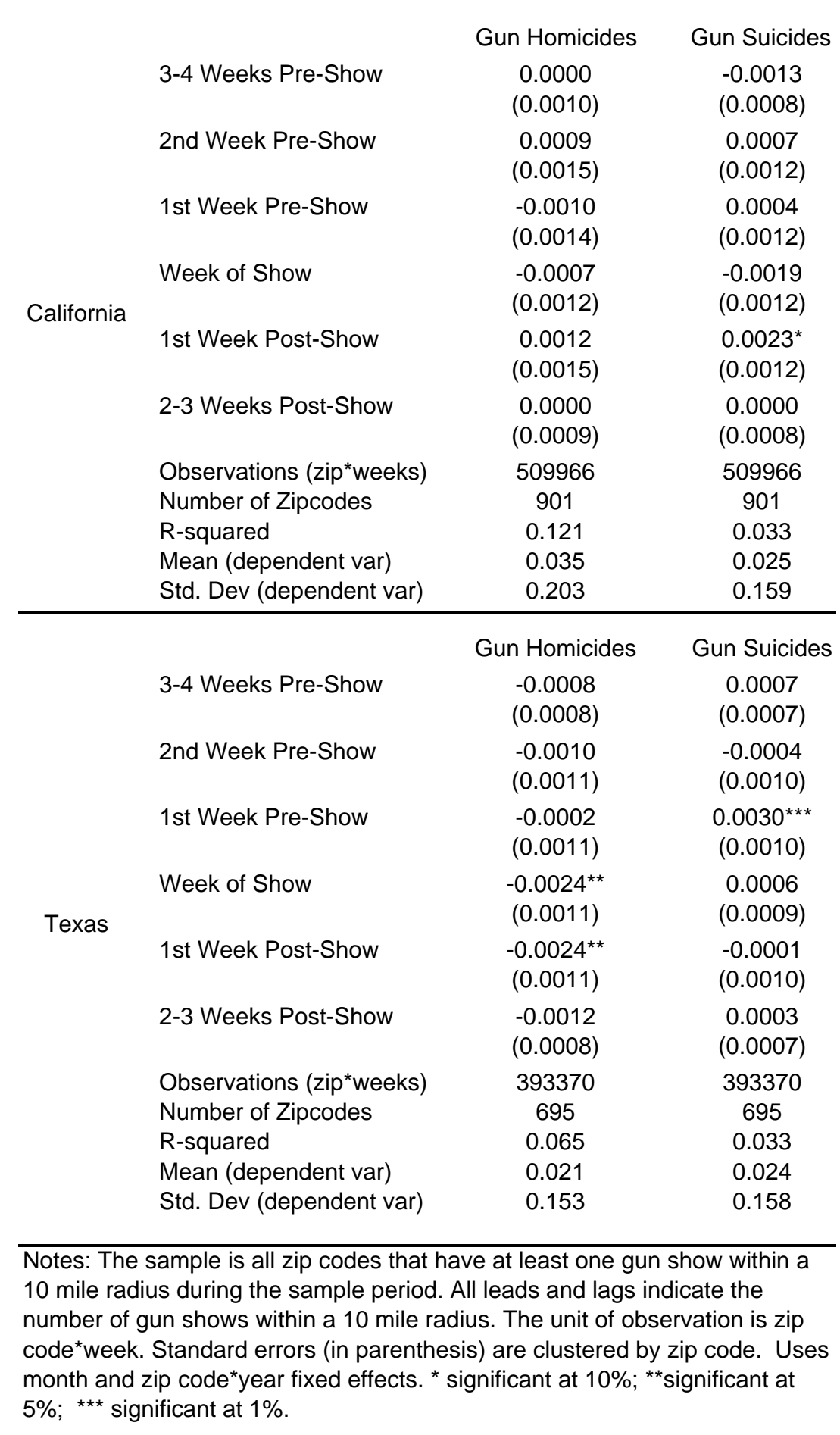


Gun Homicides

OLS, \# of deaths OLS, \# of deaths NB, \# of Poisson, \# OLS, \# of deaths

\begin{tabular}{|c|c|c|c|c|c|c|}
\hline \multirow{9}{*}{ California } & & (1) & (2) & (3) & (4) & (5) \\
\hline & Week of Show & $\begin{array}{l}-0.0007 \\
(0.0012)\end{array}$ & $\begin{array}{l}-0.0017 \\
(0.0018)\end{array}$ & $\begin{array}{l}0.965 \\
(0.340)\end{array}$ & $\begin{array}{l}0.972 \\
(0.454)\end{array}$ & $\begin{array}{l}-0.0014 \\
(0.0024)\end{array}$ \\
\hline & 1st Week Post-Show & $\begin{array}{c}0.0012 \\
(0.0015)\end{array}$ & $\begin{array}{c}0.0024 \\
(0.0025)\end{array}$ & $\begin{array}{l}1.023 \\
(0.651)\end{array}$ & $\begin{array}{l}1.038 \\
(0.498)\end{array}$ & $\begin{array}{c}0.0024 \\
(0.0030)\end{array}$ \\
\hline & 2-3 Weeks Post-Show & $\begin{array}{c}0.0001 \\
(0.0009)\end{array}$ & $\begin{array}{l}-0.0001 \\
(0.0014)\end{array}$ & $\begin{array}{l}0.994 \\
(0.871)\end{array}$ & $\begin{array}{l}0.997 \\
(0.913)\end{array}$ & $\begin{array}{c}0.0000 \\
(0.0019)\end{array}$ \\
\hline & Observations (zip*weeks) & 509,966 & 509,966 & 245,530 & 245,530 & 245,530 \\
\hline & Number of zip codes & 901 & 901 & 774 & 774 & 774 \\
\hline & R-squared & 0.121 & 0.126 & & & 0.092 \\
\hline & Mean (dependent var) & 0.035 & 0.035 & 0.073 & 0.073 & 0.073 \\
\hline & Std. Dev (dependent var) & 0.203 & 0.203 & 0.288 & 0.288 & 0.288 \\
\hline \multicolumn{7}{|c|}{ Gun Homicides } \\
\hline \multirow{9}{*}{ Texas } & & OLS, \# of deaths & OLS, \# of deaths & NB, \# of & Poisson, \# & OLS, \# of deaths \\
\hline & Week of Show & $\begin{array}{c}-0.0022^{\star *} \\
(0.0010)\end{array}$ & $\begin{array}{l}-0.0031^{*} \\
(0.0016)\end{array}$ & $\begin{array}{c}0.949 \\
(0.136)\end{array}$ & $\begin{array}{l}0.936^{\star \star} \\
(0.029)\end{array}$ & $\begin{array}{c}-0.0039 \star \star \\
(0.0019)\end{array}$ \\
\hline & 1st Week Post-Show & $\begin{array}{c}-0.0023^{\star *} \\
(0.0010)\end{array}$ & $\begin{array}{c}-0.0040^{\star *} \\
(0.0017)\end{array}$ & $\begin{array}{l}0.947^{*} \\
(0.096)\end{array}$ & $\begin{array}{l}0.932^{* *} \\
(0.047)\end{array}$ & $\begin{array}{c}-0.0041^{\star *} \\
(0.0019)\end{array}$ \\
\hline & 2-3 Weeks Post-Show & $\begin{array}{l}-0.0012 \\
(0.0008)\end{array}$ & $\begin{array}{l}-0.0029^{*} \\
(0.0015)\end{array}$ & $\begin{array}{c}0.984 \\
(0.572)\end{array}$ & $\begin{array}{c}0.969 \\
(0.255)\end{array}$ & $\begin{array}{l}-0.0020 \\
(0.0015)\end{array}$ \\
\hline & Observations (zip*weeks) & 393,370 & 393,370 & 170,761 & 170,761 & 170,761 \\
\hline & Number of zip codes & 695 & 695 & 608 & 608 & 608 \\
\hline & R-squared & 0.065 & 0.069 & & & 0.041 \\
\hline & Mean (dependent var) & 0.021 & 0.021 & 0.048 & 0.048 & 0.048 \\
\hline & Std. Dev (dependent var) & 0.153 & 0.153 & 0.230 & 0.230 & 0.230 \\
\hline
\end{tabular}

Gun Suicides

OLS, \# of deaths OLS, \# of deaths NB, \# of Poisson, \# OLS, \# of deaths

\begin{tabular}{ccccc}
$(6)$ & $(7)$ & $(8)$ & $(9)$ & $(10)$ \\
-0.0019 & -0.0015 & 0.928 & 0.928 & -0.0030 \\
$(0.0012)$ & $(0.0017)$ & $(0.140)$ & $(0.118)$ & $(0.0019)$ \\
$0.0023^{*}$ & 0.0020 & $1.091^{\star *}$ & $1.090^{\star}$ & $0.0037^{*}$ \\
$(0.0012)$ & $(0.0016)$ & $(0.050)$ & $(0.057)$ & $(0.0019)$ \\
0.0001 & -0.0001 & 1.002 & 1.001 & 0.0001 \\
$(0.0008)$ & $(0.0012)$ & $(0.941)$ & $(0.968)$ & $(0.0014)$ \\
509,966 & 509,966 & 308,743 & 308,743 & 308,743 \\
901 & 901 & 844 & 844 & 844 \\
0.033 & 0.029 & & & 0.017 \\
0.025 & 0.025 & 0.041 & 0.041 & 0.041 \\
0.159 & 0.159 & 0.203 & 0.203 & 0.203 \\
\hline
\end{tabular}

Gun Suicides

OLS, \# of deaths OLS, \# of deaths NB, \# of Poisson, \# OLS, \# of deaths $\begin{array}{lllll}0.0001 & 0.0011 & 1.005 & 1.005 & 0.0002\end{array}$

$\begin{array}{lllll}(0.0009) & (0.0014) & (0.878) & (0.892) & (0.0014)\end{array}$

$\begin{array}{lllll}-0.0005 & -0.0006 & 0.980 & 0.980 & -0.0008\end{array}$

$\begin{array}{lllll}(0.0009) & (0.0014) & (0.554) & (0.548) & (0.0014)\end{array}$

$\begin{array}{lllll}0.0000 & -0.0002 & 1.002 & 1.002 & 0.0001\end{array}$

$\begin{array}{lllll}(0.0007) & (0.0011) & (0.948) & (0.948) & (0.0011)\end{array}$

$\begin{array}{lllll}393,370 & 393,370 & 236,604 & 236,604 & 236,604\end{array}$

\begin{tabular}{|c|}
\hline 695 \\
\hline
\end{tabular}

\begin{tabular}{|c|c|}
\hline 0.033 & 0.029 \\
\hline 0.024 & 0.024 \\
\hline
\end{tabular}

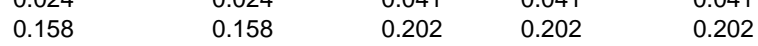

Notes: Standard errors (clustered by zip code) are in parenthesis for the OLS regressions. For NB and Poisson regressions, exponentiated coefficients are reported with p-values in parenthesis. The sample for the first two OLS regressions is zip codes with at least one gun show within a 10 mile radius during the sample period. The sample for the NB and Poisson regressions is a subset of those zip codes -

specifically, the subset of zip*weeks for which there is at least one non-zero gun death outcome variable during a given year. The regression marked "OLS, \# of deaths (limited sample)" uses the same sample as the non-linear models. The week of show, 1st week and 2-3 week lags indicate the number of gun shows within a 10 mile radius. The unit of observation is zip code ${ }^{\star} w e e k$. All regressions use month and zip code*year fixed effects. * significant at $10 \%$; ** significant at $5 \%$; ${ }^{* \star}$ significant at $1 \%$. 
Table 7. Robustness Checks, By State, Within 10 Mile Radius

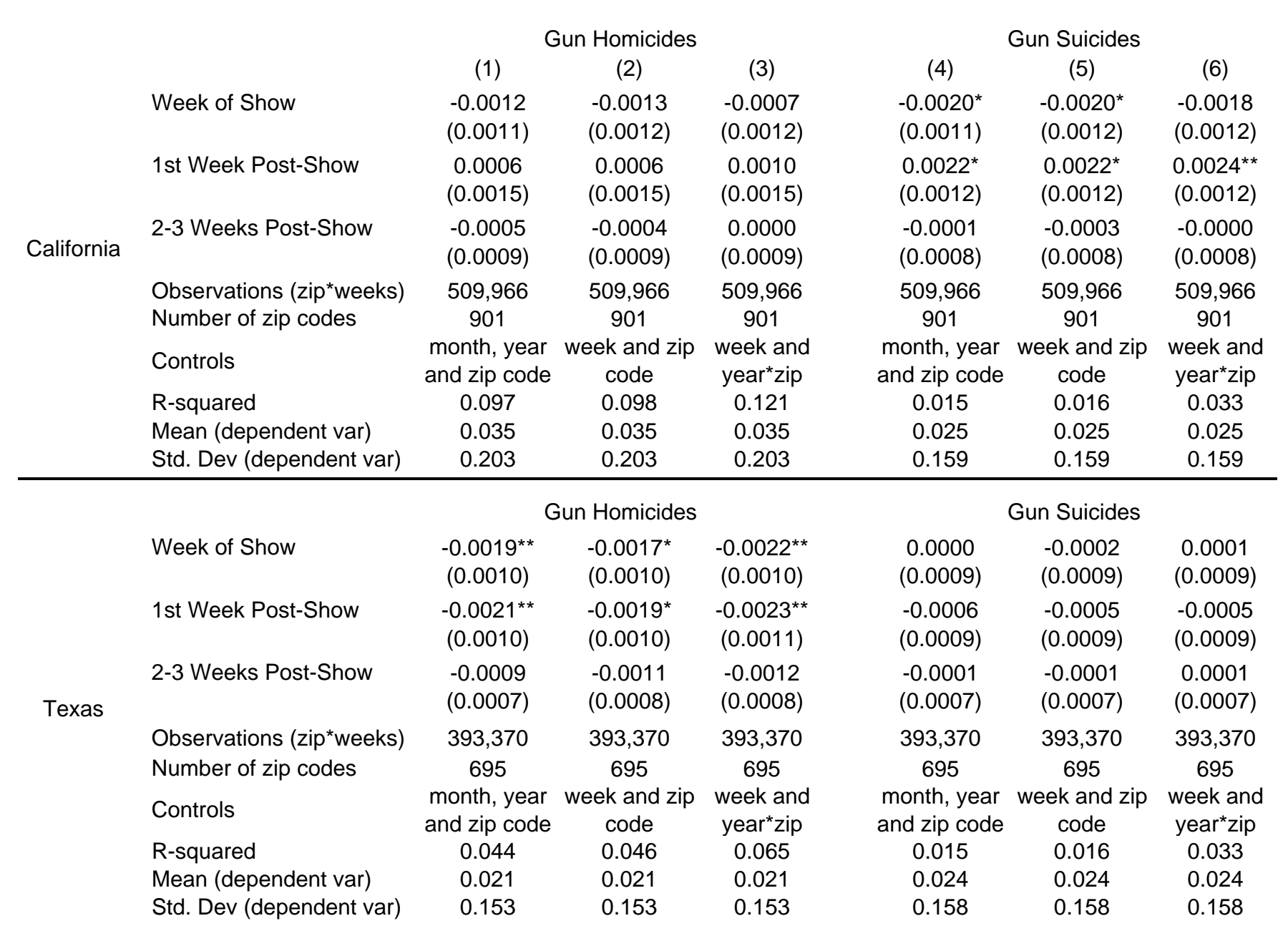

Notes: The sample for all regressions is zip codes that have at least one gun show within a 10 mile radius during the sample period. The week of show, 1st week and 2-3 week lags indicate the number of gun shows within a 10 mile radius. Columns (1) and (4) use month, year and zip code fixed effects. Columns (2) and (5) use week (definined over the entire period, i.e. 1-569) and zip code fixed effects. Columns (3) and (6) use week-of-year (i.e. 1-52) and zip code*year fixed effects. Standard errors (in parenthesis) are clustered by zipcode. The unit of observation is zip code*week. * significant at $10 \%$; ${ }^{\star *}$ significant at $5 \%$; ** significant at $1 \%$. 
Table 8. OLS, Gun Homicides and Suicides, Split by Percent Rural and Percent in Poverty, Within 10 Mile Radius

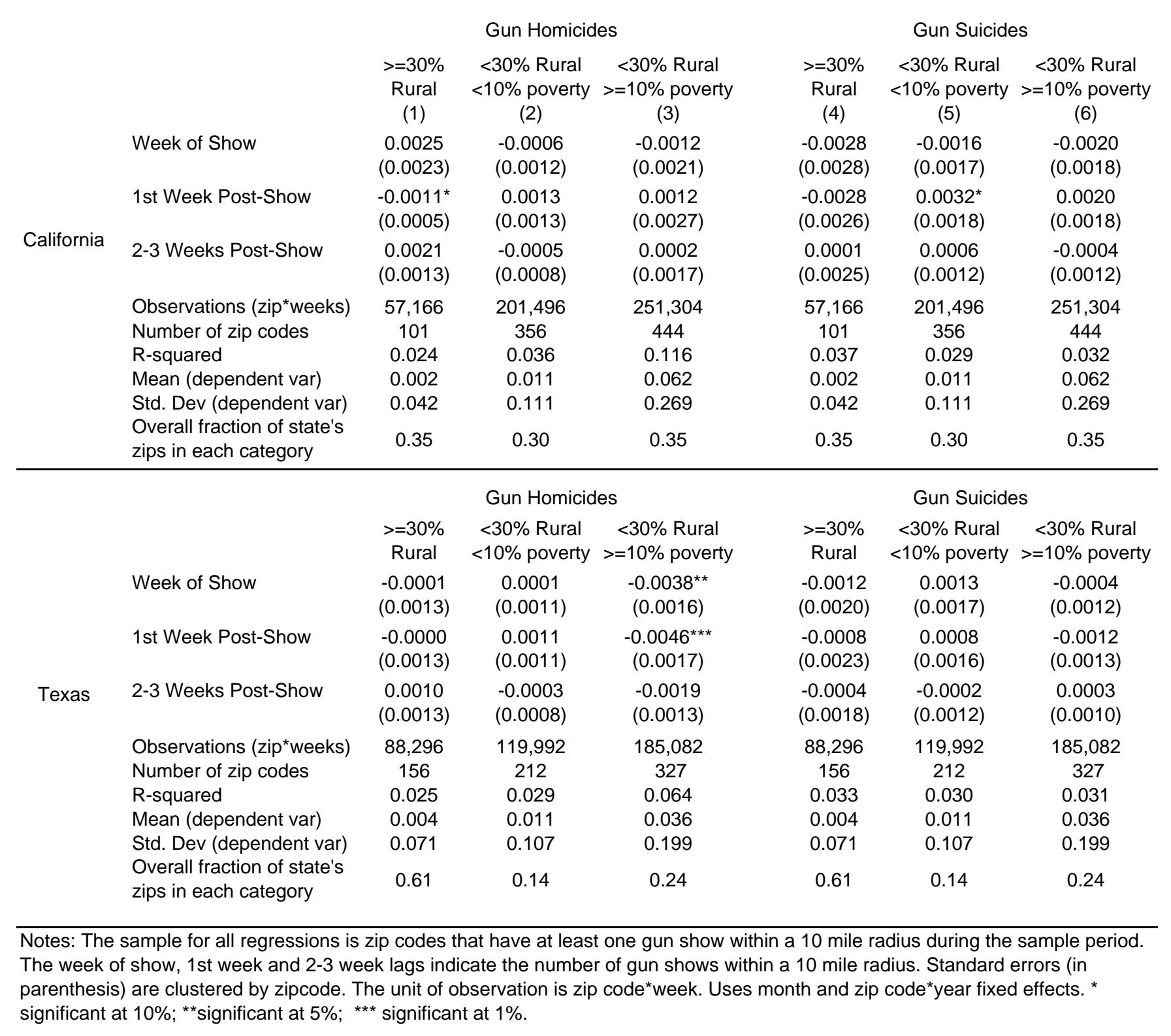


Table 9. OLS, Gun Homicides and Suicides, Split by Year, Within 10 Mile Radius

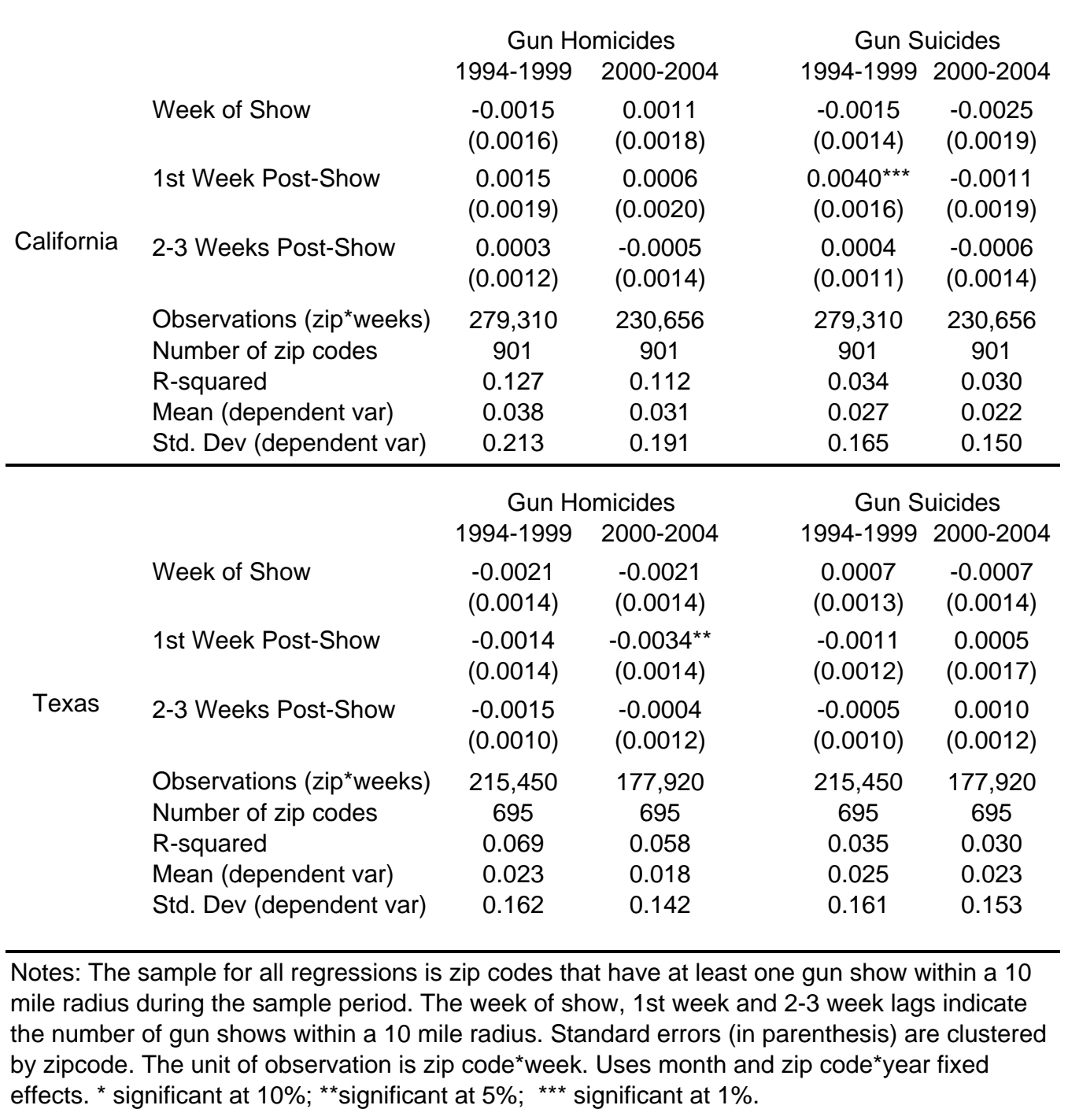


Table 10. OLS, Gun Homicides and Suicides, With Interaction Terms, Within 10 Miles Radius

\begin{tabular}{|c|c|c|c|c|c|c|c|c|c|}
\hline & & \multicolumn{4}{|c|}{ California } & \multicolumn{4}{|c|}{ Texas } \\
\hline & & $\begin{array}{l}\text { Gun Ho } \\
\text { Fraction Gun } \\
\text { Suicides } \\
\text { (1) }\end{array}$ & $\begin{array}{l}\text { omicides } \\
\text { Fraction Gun } \\
\text { Suicides/ } \\
\text { Percent Rural } \\
\text { (2) }\end{array}$ & $\begin{array}{l}\text { Gun St } \\
\text { Fraction Gun } \\
\text { Suicides } \\
\text { (3) }\end{array}$ & $\begin{array}{l}\text { fuicides } \\
\text { Fraction Gun } \\
\text { Suicides/ } \\
\text { Percent Rural } \\
\text { (4) }\end{array}$ & $\begin{array}{l}\text { Gun Hor } \\
\text { Fraction Gun } \\
\text { Suicides } \\
\text { (5) }\end{array}$ & $\begin{array}{l}\text { omicides } \\
\text { Fraction Gun } \\
\text { Suicides/ } \\
\text { Percent Rural } \\
(6) \\
\end{array}$ & $\begin{array}{l}\text { Gun St } \\
\text { Fraction Gun } \\
\text { Suicides } \\
(7)\end{array}$ & $\begin{array}{l}\text { Fuicides } \\
\text { Fraction Gun } \\
\text { Suicides/ } \\
\text { Percent Rural } \\
\text { (8) }\end{array}$ \\
\hline \multirow{3}{*}{$\begin{array}{l}\text { MAIN EFFECTS } \\
\text { (\# of gun shows } \\
\text { within zip or } 10 \\
\text { mile radius) }\end{array}$} & Week of Show & $\begin{array}{l}-0.0009 \\
(0.0012)\end{array}$ & $\begin{array}{l}-0.0008 \\
(0.0011)\end{array}$ & $\begin{array}{l}-0.0019 \\
(0.0013)\end{array}$ & $\begin{array}{l}-0.0020^{\star} \\
(0.0012)\end{array}$ & $\begin{array}{l}-0.0025^{\star *} \\
(0.0011)\end{array}$ & $\begin{array}{c}-0.0020^{\star \star} \\
(0.0009)\end{array}$ & $\begin{array}{c}0.0001 \\
(0.0010)\end{array}$ & $\begin{array}{l}-0.0003 \\
(0.0009)\end{array}$ \\
\hline & 1st Week Post-Show & $\begin{array}{c}0.0013 \\
(0.0015)\end{array}$ & $\begin{array}{c}0.0012 \\
(0.0014)\end{array}$ & $\begin{array}{l}0.0026^{\star \star} \\
(0.0013)\end{array}$ & $\begin{array}{l}0.0023^{*} \\
(0.0012)\end{array}$ & $\begin{array}{c}-0.0026^{\star *} \\
(0.0011)\end{array}$ & $\begin{array}{l}-0.0017^{\star} \\
(0.0009)\end{array}$ & $\begin{array}{l}-0.0005 \\
(0.0010)\end{array}$ & $\begin{array}{l}-0.0005 \\
(0.0010)\end{array}$ \\
\hline & 2-3 Weeks Post-Show & $\begin{array}{c}0.0001 \\
(0.0010) \\
\end{array}$ & $\begin{array}{c}0.0003 \\
(0.0009) \\
\end{array}$ & $\begin{array}{l}-0.0000 \\
(0.0009) \\
\end{array}$ & $\begin{array}{l}-0.0000 \\
(0.0009) \\
\end{array}$ & $\begin{array}{l}-0.0012 \\
(0.0009) \\
\end{array}$ & $\begin{array}{c}-0.0008 \\
(0.0007) \\
\end{array}$ & $\begin{array}{l}-0.0000 \\
(0.0008) \\
\end{array}$ & $\begin{array}{c}0.0000 \\
(0.0007) \\
\end{array}$ \\
\hline \multirow{3}{*}{$\begin{array}{c}\text { INTERACTION } \\
\text { TERMS } \\
\text { (1st Set) }\end{array}$} & Week of Show & $\begin{array}{l}-0.0068 \\
(0.0049)\end{array}$ & $\begin{array}{l}-0.0073 \\
(0.0051)\end{array}$ & $\begin{array}{l}-0.0012 \\
(0.0053)\end{array}$ & $\begin{array}{l}-0.0009 \\
(0.0055)\end{array}$ & $\begin{array}{l}-0.0102^{\star \star} \\
(0.0051)\end{array}$ & $\begin{array}{l}-0.0109 * \star \\
(0.0053)\end{array}$ & $\begin{array}{c}0.0007 \\
(0.0036)\end{array}$ & $\begin{array}{c}0.0014 \\
(0.0037)\end{array}$ \\
\hline & 1st Week Post-Show & $\begin{array}{c}0.0035 \\
(0.0057)\end{array}$ & $\begin{array}{c}0.0038 \\
(0.0061)\end{array}$ & $\begin{array}{c}0.0084 \\
(0.0058)\end{array}$ & $\begin{array}{c}0.0096 \\
(0.0061)\end{array}$ & $\begin{array}{l}-0.0113^{\star *} \\
(0.0046)\end{array}$ & $\begin{array}{c}-0.0126^{\star \star \star} \\
(0.0047)\end{array}$ & $\begin{array}{c}0.0031 \\
(0.0043)\end{array}$ & $\begin{array}{c}0.0032 \\
(0.0044)\end{array}$ \\
\hline & 2-3 Weeks Post-Show & $\begin{array}{r}0.0007 \\
(0.0046) \\
\end{array}$ & $\begin{array}{l}-0.0004 \\
(0.0048) \\
\end{array}$ & $\begin{array}{l}-0.0034 \\
(0.0037) \\
\end{array}$ & $\begin{array}{l}-0.0035 \\
(0.0037) \\
\end{array}$ & $\begin{array}{l}-0.0054 \\
(0.0039) \\
\end{array}$ & $\begin{array}{l}-0.0061 \\
(0.0041) \\
\end{array}$ & $\begin{array}{l}-0.0020 \\
(0.0029) \\
\end{array}$ & $\begin{array}{l}-0.0021 \\
(0.0030) \\
\end{array}$ \\
\hline \multirow{13}{*}{$\begin{array}{l}\text { INTERACTION } \\
\text { TERMS } \\
\text { (2nd Set) }\end{array}$} & Week of Show & & $\begin{array}{c}0.0019 \\
(0.0036)\end{array}$ & & $\begin{array}{l}-0.0013 \\
(0.0047)\end{array}$ & & $\begin{array}{c}0.0038 \\
(0.0028)\end{array}$ & & $\begin{array}{l}-0.0035 \\
(0.0031)\end{array}$ \\
\hline & 1st Week Post-Show & & $\begin{array}{l}-0.0016 \\
(0.0038)\end{array}$ & & $\begin{array}{l}-0.0053 \\
(0.0046)\end{array}$ & & $\begin{array}{l}0.0071^{\star *} \\
(0.0030)\end{array}$ & & $\begin{array}{l}-0.0006 \\
(0.0035)\end{array}$ \\
\hline & 2-3 Weeks Post-Show & & $\begin{array}{l}0.0049^{\star} \\
(0.0029) \\
\end{array}$ & & $\begin{array}{r}0.0005 \\
(0.0033) \\
\end{array}$ & & $\begin{array}{c}0.0042 \\
(0.0027) \\
\end{array}$ & & $\begin{array}{r}0.0002 \\
(0.0025) \\
\end{array}$ \\
\hline & Observations (zip*weeks) & 493,552 & 493,552 & 493,552 & 493,552 & 379,786 & 379,786 & 379,786 & 379,786 \\
\hline & Number of zip codes & 872 & 872 & 872 & 872 & 671 & 671 & 671 & 671 \\
\hline & R-squared & 0.120 & 0.120 & 0.032 & 0.032 & 0.064 & 0.064 & 0.032 & 0.032 \\
\hline & Mean (dependent var) & 0.036 & 0.036 & 0.036 & 0.036 & 0.022 & 0.022 & 0.022 & 0.022 \\
\hline & Std. Dev (dependent var) & 0.207 & 0.207 & 0.207 & 0.207 & 0.156 & 0.156 & 0.156 & 0.156 \\
\hline & 10th Pcntl (interaction var) & 0.278 & 0.000 & 0.278 & 0.000 & 0.400 & 0.000 & 0.400 & 0.000 \\
\hline & 25th Pcntl (interaction var) & 0.393 & 0.000 & 0.393 & 0.000 & 0.500 & 0.000 & 0.500 & 0.000 \\
\hline & 50th Pcntl (interaction var) & 0.481 & 0.000 & 0.481 & 0.000 & 0.621 & 0.009 & 0.621 & 0.009 \\
\hline & 75th Pcntl (interaction var) & 0.571 & 0.034 & 0.571 & 0.034 & 0.700 & 0.212 & 0.700 & 0.212 \\
\hline & 90th Pcntl (interaction var) & 0.667 & 0.274 & 0.667 & 0.274 & 0.800 & 0.710 & 0.800 & 0.710 \\
\hline
\end{tabular}

Notes: The sample for all regressions is zip codes that have at least one gun show within a 10 mile radius during the sample period. The main effects indicate the number of gun shows during that lag within a 10 mile radius. The first set of interaction terms is each lag multiplied by the demeaned "fraction gun suicide" variable. The second set of interaction terms is each lag multiplied by the demeaned percent rural variable. Fraction gun suicide and percent rural are demeaned by their average over the observations in the regression sample. Percentiles listed for the two-interaction regressions are for percent rural; the percentiles for fraction gun suicide are the same as in the one-interaction regressions.

Standard errors (in parenthesis) are clustered by zipcode. The smaller number of observations for the regression with the "fraction gun suicide" interaction is because this variable is missing for zip codes with zero suicides over the entire period. The unit of observation is zip code*week. Uses month and zip*year fixed effects. * significant at $10 \%$; ${ }^{*}$ significant at $5 \%$; $* * *$ significant at $1 \%$. 
Appendix Table 1. Demographic, Gun Show and Gun Death Characteristics for California and Texas Zip Codes

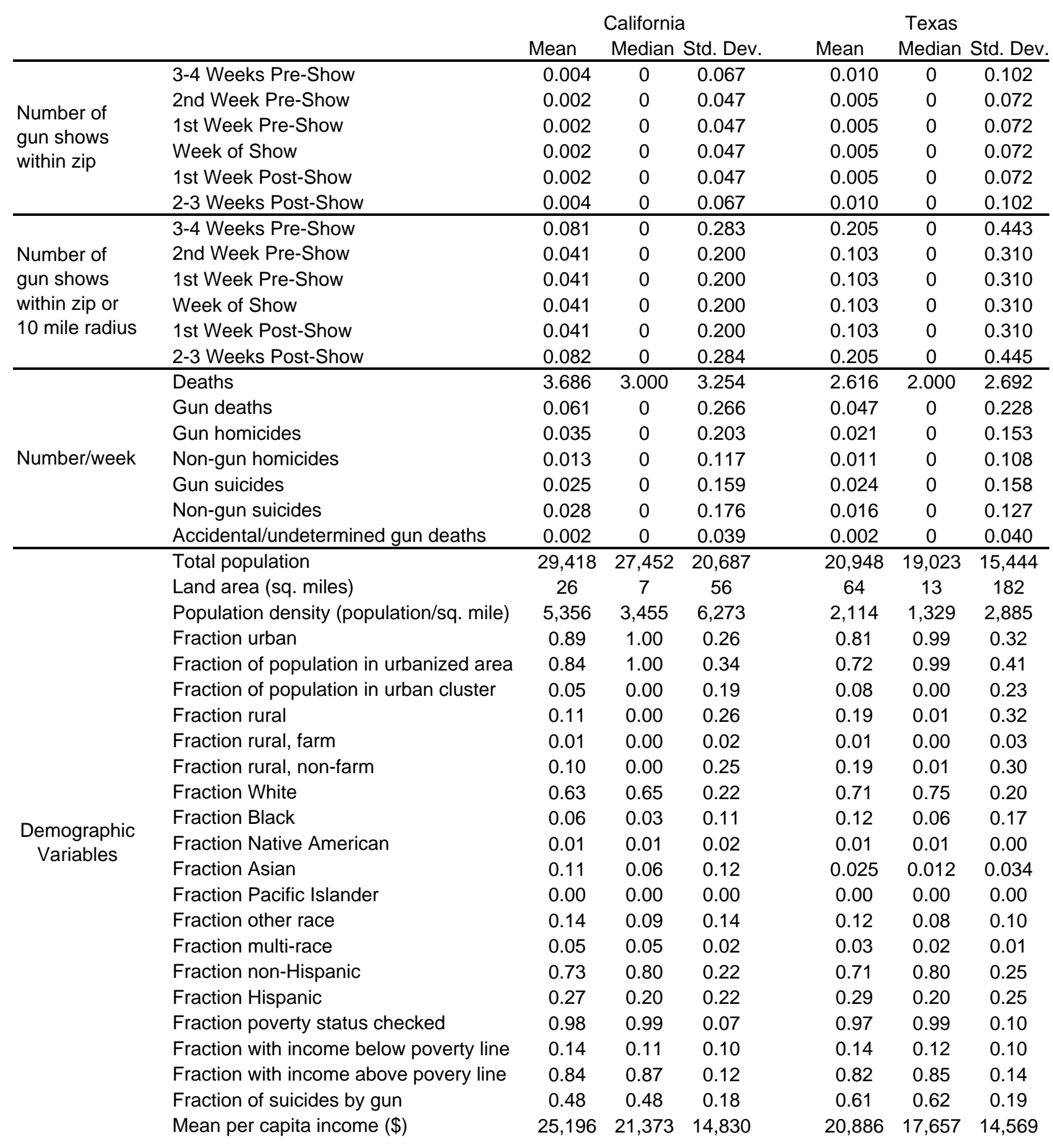

Notes: The sample is limited to zip codes with at least one gun show within a 10 mile radius show during the sample period. In California, this corresponds to 901 zip codes and 509,966 zip*years. In Texas, this corresponds to 695 zip codes and 393,370 zip*years. In rows 1 through 6, the leads and lags indicate the number of gun shows within the zip code during that lead/lag. For rows 7 through 12, the leads and lags indicate the number of gun shows within a 10 mile radius during that lead/lag. The unit of observation is zip code*week. 
Figure 1. Number of Gun Shows by State and Year

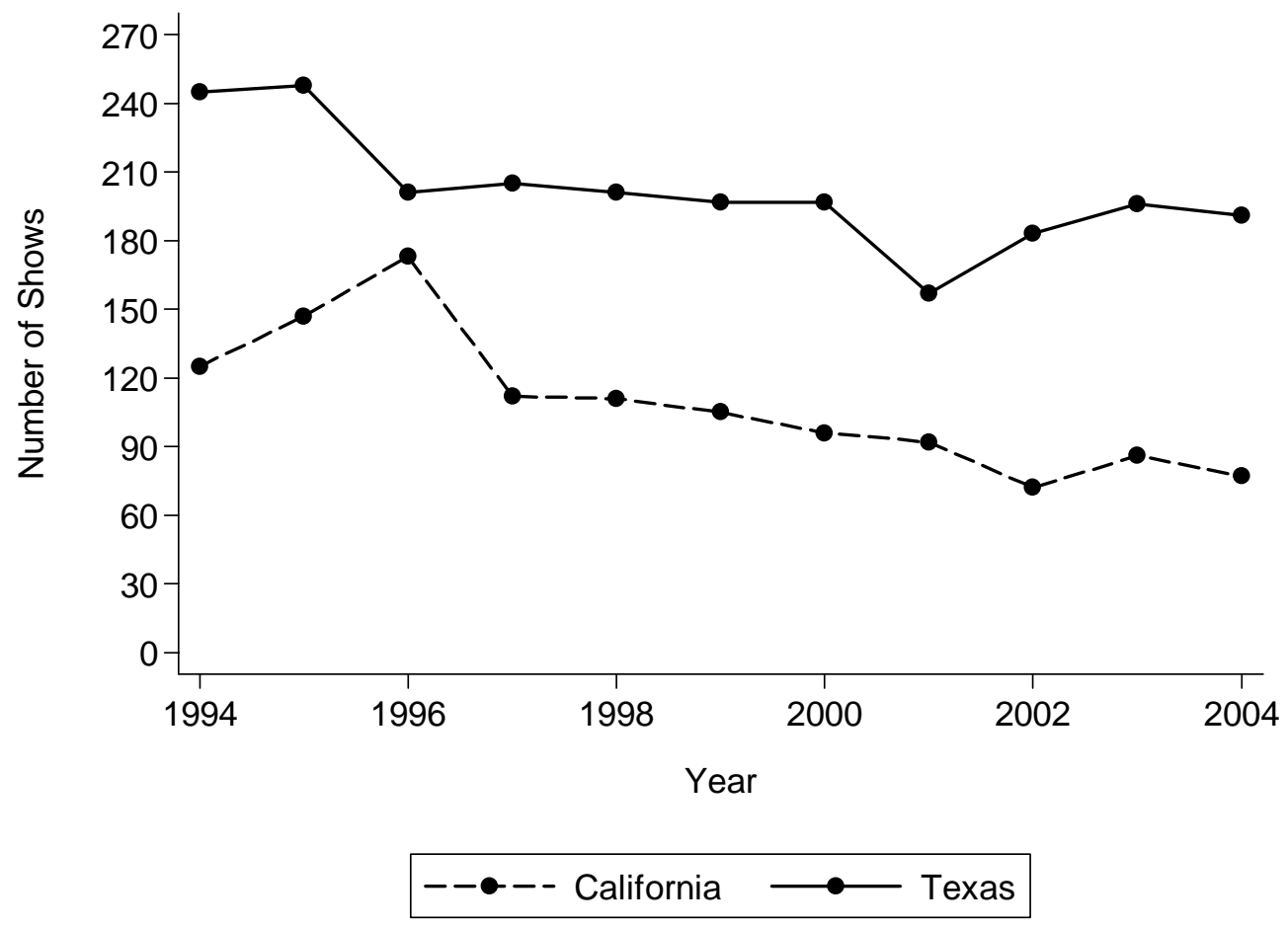

Figure 2. Number of Gun-Related Deaths by State and Year

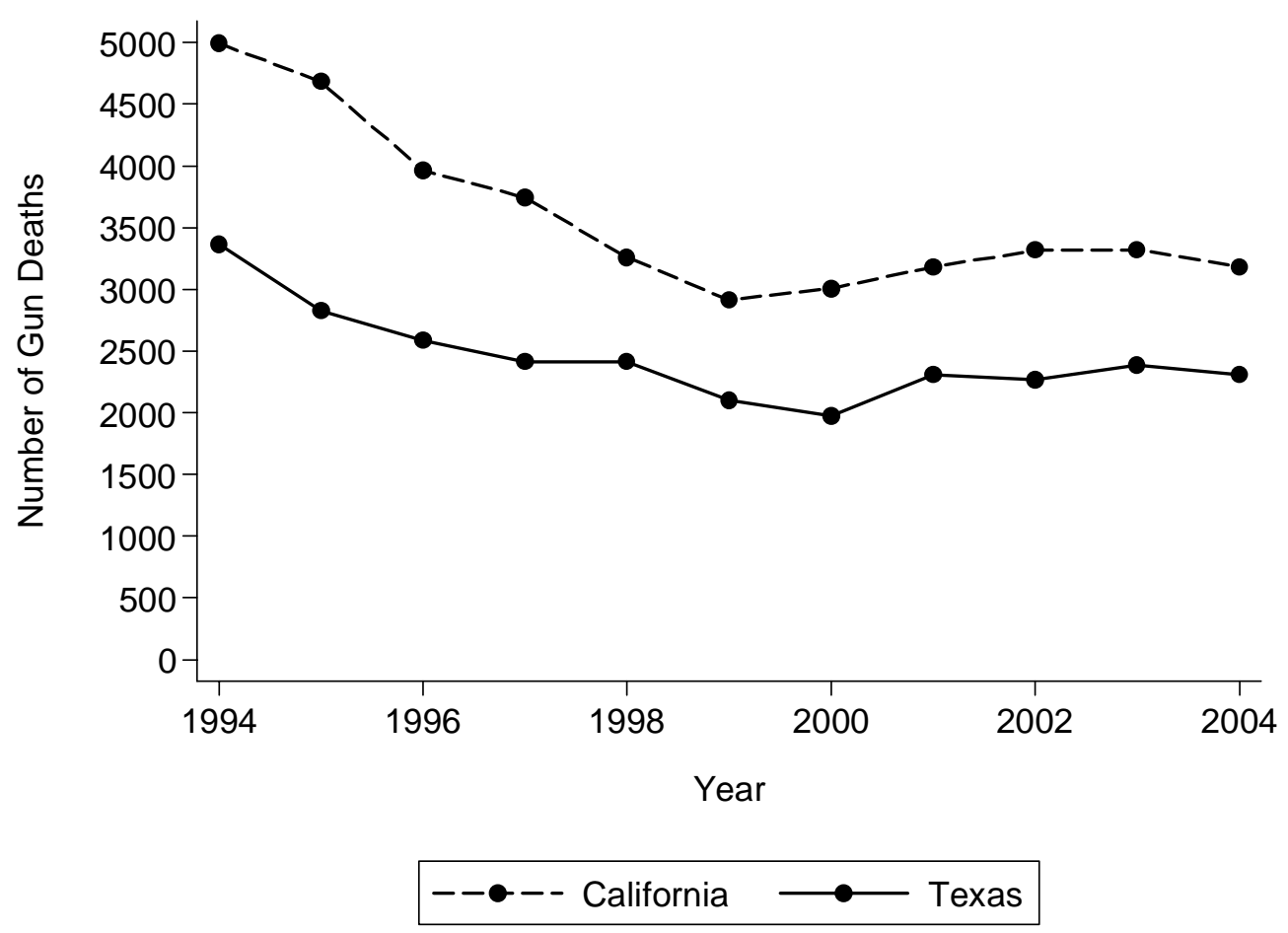

